\title{
6 Overview of harbours in Iceland
}

The following sections will discuss specific harbours in Iceland in detail. To facilitate comparison, it will follow the same structure as Jón Aðils's overview of Icelandic harbours during the Danish trade monopoly, which follows the coastline of Iceland in clockwise direction, starting with the Vestmannaeyjar in the southwest. The reader looking for a more condensed overview of the trading places in Iceland may wish to begin with the general discussion of Icelandic harbours in Section 5.1 and the timeline of Icelandic harbours supplied with the printed book or downloadable as additional online material at https://doi.org/ 10.1515/9783110655575-018 or with Appendix A, which contains overviews of the licences issued from 1565 onwards. Much of the overview here is based on the licences and the donation register of the confraternity of St Anne in Hamburg, which usually have not been referenced in the footnotes. In these cases, the appropriate references can be found in the appendices.

\subsection{Vestmannaeyjar}

Names in the sources: Vespenøøe; Wespene; Wespeno; Wespenow

The Vestmannaeyjar ('Westman Islands') are a group of 14 small islands off the southwestern coast of Iceland, southeast of the Reykjanes peninsula. Only the largest of these islands, Heimaey, was and is inhabited. In the northern part of this island is a bay on which the trading station in the islands in Danish times and likely before was located, with buildings erected on the bay's southern shore. The tiny size of the islands contrasts sharply with their importance as a trading site, which was due to the rich fishing grounds that surround them. Each winter, large numbers of fishermen would flock here from the mainland to fish and then sell their catch to foreign merchants the following summer. Historical sources report that the fishing was sometimes so good here that some portion of the catch could not be processed and had to be thrown away. ${ }^{1}$

The Vestmannaeyjar have a history that is quite distinct from that of the rest of Iceland. They were often treated separately by the Danish crown, especially after the islands became the personal property of the king in $1420 .^{2}$ During the

1 Aðils, Monopolhandel, 279-281; P. E. Kristian Kålund, Bidrag til en historisk-topografisk Beskrivelse af Island, vol. 1 (Copenhagen, 1877), 278-279.

2 Porláksson, “Urbaniseringstendenser”, 180.

Ә Open Access. (C 2020 Bart Holterman, published by De Gruyter. (cc) BY-NC-ND This work is licensed under a Creative Commons Attribution-NonCommercial-NoDerivatives 4.0 International License.

https://doi.org/10.1515/9783110655575-006 


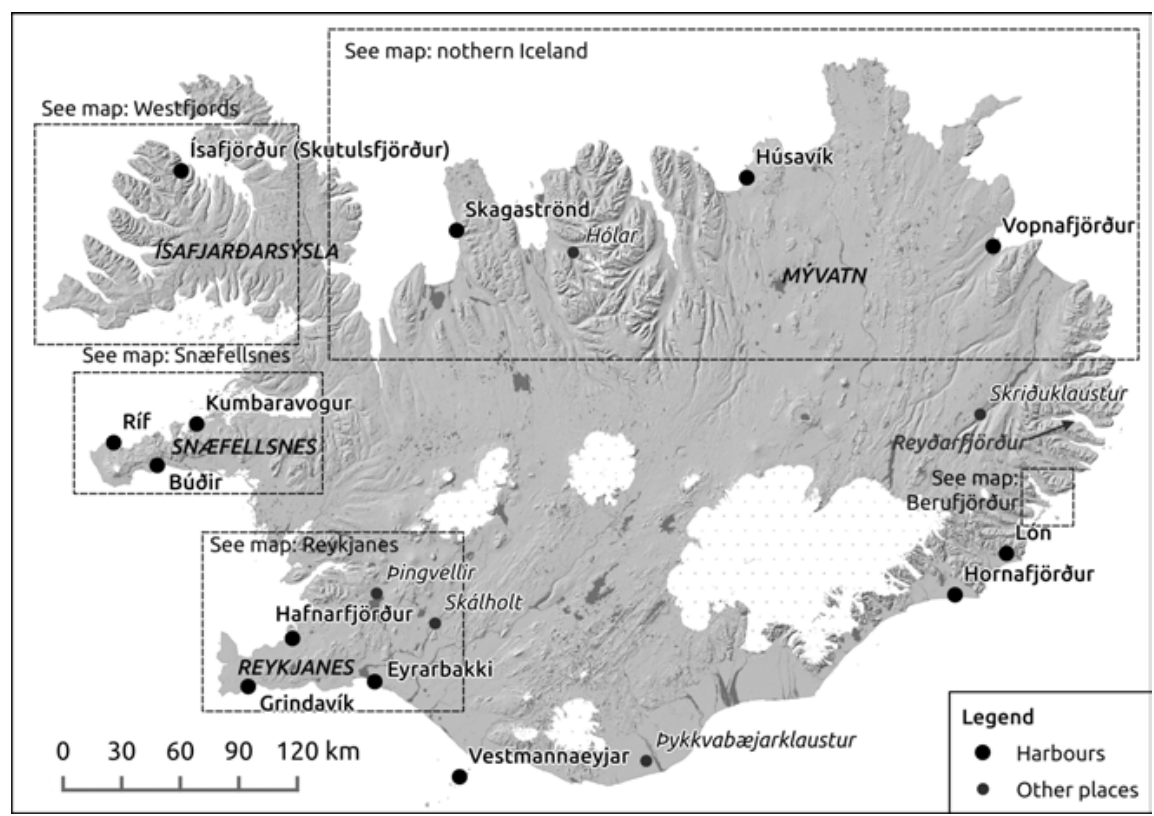

Figure 6.1: Map of Icelandic harbours and other places mentioned in the text. For the detail maps, see Figure 6.2 (Reykjanes); Figure 6.5 (Snæfellsnes); Figure 6.12 (Westfjords); Figure 6.13 (northern Iceland); and Figure 6.14 (Berufjörður).

Danish trade monopoly, the islands were often licensed under different conditions than the other harbours on the mainlland. ${ }^{3}$ In earlier times, one of the most important harbours for the English merchants was located on the islands, who built a stronghold and houses here in the fifteenth century. In the wake of the conflicts with German merchants in the 1530s, the English concentrated their Icelandic activities in the Vestmannaeyjar until around 1558, when the islands were given to Simon Surbeck, who later became burgomaster of Copenhagen. He was able to limit the influence of the English, although they appeared regularly throughout the rest of the century. ${ }^{4}$ Afterwards, the islands continued to be leased

3 Aðils, Monopolhandel, 279-280.

4 Porsteinsson, “Island”, 187; Porláksson, “Urbaniseringstendenser”, 179-180; Aðils, Monopolhandel, 48-52. 
to Danish merchants, one of whom served as the sheriff there; the merchants appointed a deputy who would stay in winter. ${ }^{5}$

Curiously, there is hardly any evidence for German activity on the islands, except in the years 1547 and 1548, when Hamburg merchant Joachim Wullenwever received the right to trade there. However, the Hamburg merchants who sailed for Wullenwever, led by merchant Hans Wegener, ran into many difficulties as their presence coincided with the lease of Iceland to Copenhagen in 1547. That year they arrived in the islands too late to trade and had to leave their goods there, only to find when they returned the following year that their goods had been confiscated by the new governor Lorenz Mule. To make matters worse, Hans Wegener and his servants were kidnapped by English merchants and taken to England, allegedly on the orders of Mule. ${ }^{6}$ Although the dispute between Copenhagen and the Hamburg merchants was settled in 1551, there seems to have been no further activity of German merchants on the Vestmannaeyjar.

\subsection{Southwestern Iceland: Reykjanes peninsula and surroundings}

Alongside Vestmannaeyjar and Snæfellsnes, the fishing grounds around the Reykjanes peninsula were among the best in Iceland. Moreover, almost all important administrative centres were located in the southwestern part of the island, such as the royal farm of Bessastaðir, where the governor was seated; the site of the annual Althing in Pingvellir; and the bishopric of Skálholt. It is therefore not surprising that this area was the focus of German activity in Iceland: it was marked by the highest density of sites of both trading and of conflict with English traders and the Danish authorities.

\subsubsection{Eyrarbakki / Porlákshöfn}

Names in the sources:

Eyrarbakki: Ohrbach; Oerback; Orbackhaffen; Ørneback

5 These were: in 1558, Simon Surbeck; in 1582, Jørgen Kydt; in 1583, Niels Sørensen; in 1586, Oluf Matzen (all from Copenhagen); and in 1590, Poul Pedersen (Aarhus). Aðils, Monopolhandel, 46-47, 279; on the royal Danish trade in the Vestmannaeyjar, see Pétur G. Kristjánsson, "Tengsl framleiðslu og markaðar. Konungsumboðið í Vestmannaeyjum og utanlandsverslun Íslendinga á síðari hluta 16. aldar” (Master’s thesis, Háskoli Îslands, 2008).

6 SAH 111-1 Islandica, vol. 2: complaints from 1549/1550 (15490000HAM00, 15500000HAM03). 


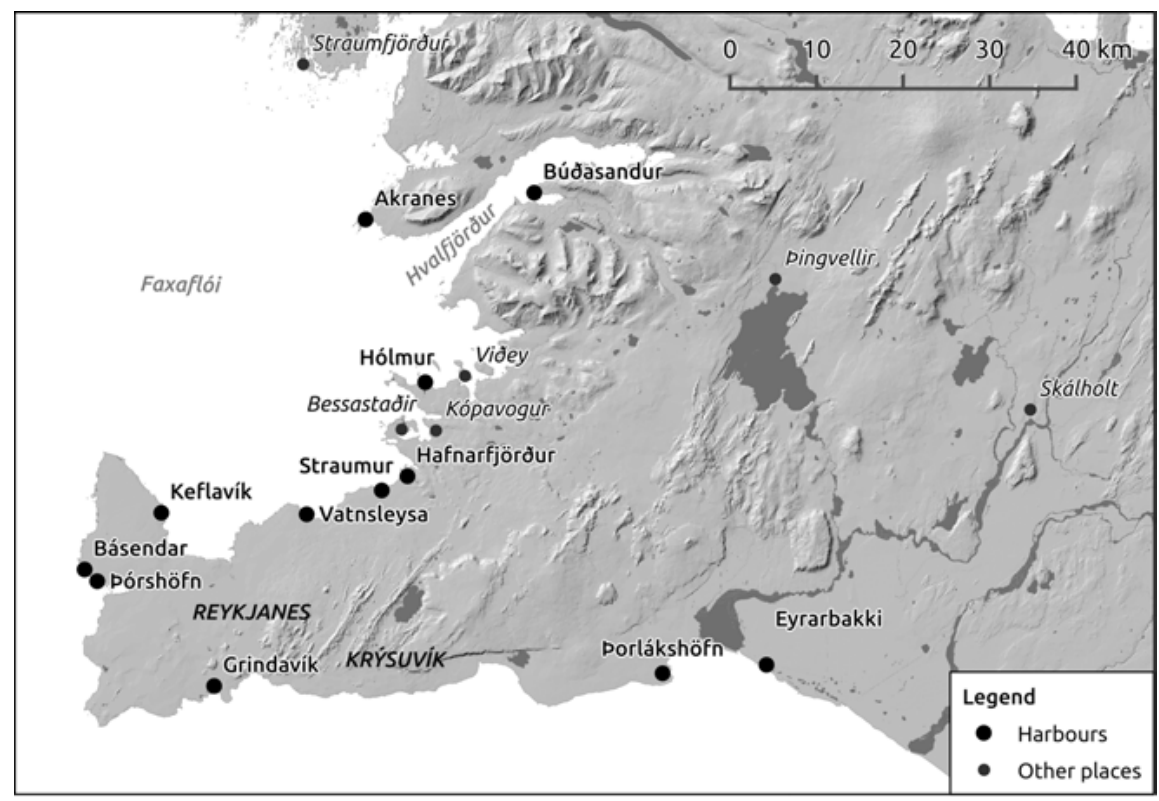

Figure 6.2: Map of trading sites and other locations around the Reykjanes peninsula. See Figure 6.1 for location.

Porlákshöfn: Thorlagshaffen; Thorlakshaffe; Thorlangs hafe; Thorlaxhaffen; Torlakeshaven

Eyrarbakki, located near the mouth of the River Ölfusá, was one of the few harbours on the southern coast of Iceland. It served as the trading place for the diocese of Skálholt, which is about $40 \mathrm{~km}$ inland. Before 1361, the place was known as Eyrar, which referred to the entire stretch of coast between the two rivers Ölfusá and pjórsá, about 20 km long. After 1386, it became known as Eyrarbakki, with the main harbour at the farm Einarshöfn, which belonged to the church in Skálholt, close to the modern town of Eyrarbakki. ${ }^{7}$

Eyrarbakki was associated with the largest district of all harbours in Danish times, a district that covered almost the entire southern coast east of the harbour. ${ }^{8}$ Due to the many farmers in this area, Eyrarbakki was known in Danish times as both a butcher's and a fish harbour. German and Danish merchants in Eyrarbakki, however, were mostly interested in fish products. Except for a short

7 Porláksson, “Urbaniseringstendenser”, 169; Kålund, Beskrivelse af Island, 1877, 1:174-75; Vigfús Guðmundsson, Saga Eyrarbakka, vol. 1 (Reykjavik, 1945), 23-31.

8 Aðils, Monopolhandel, 281. 
period in the early eighteenth century, livestock from the region was probably brought to Hafnarfjörður to be butchered and sold as meat. ${ }^{9}$

The location along the unprotected southern beach presented difficulties for those wanting to use the harbour. Not only was the harbour notoriously hard to navigate, with a ship often having to wait for days for the right winds to enter, but it was small as well, only able to accommodate one ship at a time. ${ }^{10}$ In addition, the buildings on the shore east of the harbour were in frequent danger of flooding. Seventeenth-century descriptions from the site speak of a large storehouse of the bishop erected on poles and many (fishing) booths, which were moved at the end of the seventeenth century because of the flooding. ${ }^{11}$

As a trading place for the bishop of Skálholt, the bishop's own ship is mentioned as using the harbour every now and then between 1280 and $1520 .^{12}$ Afterwards the bishop seems to have traded mainly with Hamburg merchants, about whom we are quite well informed through the accounts of bishop Gizur Einarsson (1540-1548). ${ }^{13}$ These show frequent interactions with German merchants in Hafnarfjörður (notably Hinrick Hintzke) and Eyrarbakki (Hans van Lubbeke). ${ }^{14}$ The first certain mention of the presence of Hamburg merchants in Eyrarbakki is bishop Gizur's payment to Hans van Lubbeke for lime and bricks for the construction of two chimneys on the site in 1541 (possibly for a storage house), which Van Lubbeke promised to bring the next year. ${ }^{15}$ It might be that Van Lubbeke was really from Lübeck and still had connections there, as in the 1551 accounts of Eggert Hannesson, Cordt Stael and Cordt Vebbeke are mentioned as Lübeck merchants in "Syderhaffen" ('southern harbour'), which might be Eyrarbakki. ${ }^{16}$ The next year, Eggert's accounts mention the ship of Cordt Lunenberg from Hamburg in nearby Porlákshöfn. ${ }^{17}$

\section{Aðils, 281-282.}

10 Kålund, Beskrivelse af Island, 1877, 1:175; Aðils, Monopolhandel, 283.

11 Porláksson, "Urbaniseringstendenser”, 169; Aðils, Monopolhandel, 284; Guðmundsson, Saga Eyrarbakka, 1:31-36.

12 Porláksson, “Urbaniseringstendenser”, 169.

13 Reykjavík, Stofnun Árna Magnússonar, AM 232 8vo: Bréfabók Gissurar biskups Einarssonar, 1540-1548. Most of these documents (of which there are many) have been published in $D I 10$.

14 Guðmundsson, Saga Eyrarbakka, 1:269. See also Sections 4.3.3 and 4.5.

15 "Item skrifad hans lubeck til vm ij ackeri, vm tigelstein og kalk suo sem til tueggia skorsteina ef hann uill biggia ad are komanda a eyrarbakka”. DI 10:393.

16 DI 12:222; Bei der Wieden, "Lübeckische Islandfahrt", 17. Cordt Stael is also attested in the donation register of St Anne as a servant in Básendar in the 1540s.

17 DI 12:323. 
In the donation register of the confraternity of St Anne, Eyrarbakki is mentioned for the first time in 1556, and from this point on it is usually the name of merchant Herman Wegener who is listed. With some certainty, ships from the donation register can be connected to Eyrarbakki until 1564 and from 1570 onwards until the introduction of the Danish trade monopoly. During the intervening years, Bremen merchants seem to have taken over the harbour. In 1567, they requested a licence for this harbour together with Berufjörður ("Ostforde”), Búðir, and Kumbaravogur, the only harbours the Hamburg merchants "had not driven them out [of] yet”, thereby representing the temporary absence of Hamburg traders in Eyrarbakki in their own favour. ${ }^{18}$

However, a licence for Eyrarbakki, combined with Porlákshöfn, was issued that same year to Johan Jellesen Falckner, Danish factor in Amsterdam, tasked with bringing sulphur from Iceland for the manufacture of gunpowder in Antwerp. ${ }^{19}$ In 1571, Falckner's licence was renewed, with the provision that he was allowed to mine metals, sulphur, copper, or alum in the trading district. In March 1578, Luder Ottersen from Lübeck and Danish merchant Jørgen Kydt were granted the licence for ten years. ${ }^{20}$ Kydt was appointed as a merchant on the royal ship sailing to Iceland for that year as well. ${ }^{21}$ However, in the next year there is evidence for Herman Wegener having returned to the harbour to trade. The situation becomes clearer in 1586, when Herman Wegener requested a licence for Eyrarbakki and Porlákshöfn himself, and promised to pay the tolls for the harbours separately. The reason to combine the licence for Eyrarbakki with that for Porlákshöfn, a big farm located on the other side of the River Ölfusá renowned for the quality of its fishing grounds, ${ }^{22}$ was that fish were not so abundant in Eyrarbakki. ${ }^{23}$ However, it is unclear why Porlákshöfn needed to be mentioned explicitly, especially for the double toll amount, as the

18 SAB 2-R.11.ff.: instruction for Tyleman Zerneman, 26 September 1567 (15670926BRE00).

19 KB 1566-1570, 313; DI 14:415. Falckner appears earlier in the 1560s in relation to the Faroe Islands, when he was ordered by the king to supply goods for the fitting out of warships and stockfish to feed their crews: KB 1561-1565, 646; 1566-1570, 65. See also Sections 2.1.1.1 and 3.6.

20 KB 1576-1579, p. 325; Guðmundsson, Saga Eyrarbakka, 1:271-272.

21 On 5 September 1577. KB 1576-1479, p. 233.

22 Kålund, Beskrivelse af Island, 1877, 1:83.

23 "dewile duße haffen unglick mit dem fischfang gesegnet, also bidden se dat ein paß up beide hafen up Herman Wegener gnedigst gestellet werde, darjegen sie i. kon. may. vor beide haffen insonderheit den tollen geven und entrichten willen, we bethero geschen."RAK D11, Pakke 28 (ad Suppl. II, 25) (15860213HAM00). 
two harbours were close to one another and probably in the same trading district. Possibly the reason was that fish from Porlákshöfn had been brought to merchants in Grindavík before, as it is also known from the Danish period. ${ }^{24}$

A list of harbours in use in Iceland compiled some years later for the German Chancery in Copenhagen mentions that Wegener (this time called Marten) sailed for Luder Ottersen to Eyrarbakki and Porlákshöfn. ${ }^{25}$ It is likely that Wegener had sailed for Ottersen and Kydt from 1579 onwards, and this proved to be an enduring arrangement. In November 1590, Luder Ottersen was granted the licence for Eyrarbakki and Porlákshöfn for three years in his own name again, and a new licence (this time without mentioning Porlákshöfn) was issued to him in January 1598 for another three years. Although there are no licences known for the period in between (1594-1597), Herman Wegener, and from 1595 to 1603 Andreas Wegener (probably Herman's brother or son), can be attested as having sailed to Eyrarbakki from the donation register. It is likely that they were sailing for Luder Ottersen the entire time.

\subsubsection{Grindavík}

Names in the sources: Grenewick; Grenwyck; Grindewich; Grindelwiecke; Grindewickeshave; Grindewigh; Grindvig; Gronewick; Grundewyck; Gryndewyck; Gunderwigk

Located on the southern coast of the Reykjanes peninsula, Grindavík was one of the three most important harbours for the English merchants in the fifteenth century. ${ }^{26}$ Known in older times as Stadarsund, Stadarvik, or Stadarhavn, it was a notoriously difficult harbour to enter, especially when the wind was out of the south. Nor was it particularly sheltered: the custom of mooring the ships using the iron rings there did not prevent frequent shipwrecks, such as the first Danish ship to sail there in 1602. During certain periods, the Danes therefore sailed to nearby Básendar instead, and posted a merchant in Grindavík. ${ }^{27}$

24 Aðils, Monopolhandel, 287.

25 RAK D11, Pakke 24 (Suppl. II, 7): list of licensed harbours, 1584-1592 (15840000KOB00). The document also states that it was unclear whether Wegener actually received a licence. However, a note on his request (see note 23 above), does state that all Hamburg licences asked for in the document were granted. On the other hand, in $1586 \mathrm{Kydt}$ and Ottersen's licence would still have been valid for two years.

26 Porláksson, “Urbaniseringstendenser”, 180.

27 Aðils, Monopolhandel, 284-287; Kålund, Beskrivelse af Island, 1877, 1:40-41. 
Grindavik was predominantly a harbour for stockfish produced on the southern coast of Reykjanes, its district encompassing only the harbour's immediate surroundings and those of neighbouring Krýsuvík in Danish times. ${ }^{28}$ The Krýsuvík area was also known for sulphur mining, so it could well be that sulphur was also exported from Grindavík, although sources from the English period tell only of sulphur being brought to Straumur, on the northern coast of the peninsula. ${ }^{29}$ Sulphur trade involving German merchants, however, is only known from the harbours in the north near the more-productive mines near Mývatn.

German merchants are not known to have used Grindavik in the early sixteenth century, possibly concentrating their business in nearby Básendar. It became the last stronghold for the English on the Icelandic mainland after they were largely driven out of Hafnarfjörður by the Germans. It is in Grindavík that 280 German merchants, led by bailiff Didrick van Minden, attacked the ship of John Breye and killed 15 men on board in 1532. The reason for this was Breye's alleged ill treatment of Icelanders and the theft of a quantity of stockfish that the German merchants in Hafnarfjörður had purchased. ${ }^{30}$ In one of the documents produced by English ambassador Thomas Lee in Germany the next year, it is stated that "no Bremen or Hamburg ships were in the harbour called Grindavík at the time". 31

After this incident, the English seem to have disappeared from Grindavik, but it is unclear if the harbour was used by German merchants continuously from that point onwards. Eggert Hannesson's accounts mention Bremen skipper Luder Kock as having been there in $1552,{ }^{32}$ and in 1556 a ship with skipper Reineke Grelle and merchants Arndt vam Hagen and Matthias Cordes is attested as having sailed to Grindavík in the donation register of the confraternity of St Anne in Hamburg. This was probably an exception, as these three did not sail together in other years. In the winter of 1565/6, Herman Schomaker and Herman Krechting from Bremen applied for licences for Grindavík and Keflavík. They had sailed there the year before with two ships, one of which they had lost in the former harbour, "partly because of the dangerousness of the bad harbour", partly because of bad weather; they had managed to salvage most of their goods,

28 Aðils, Monopolhandel, 284-287.

29 Mehler, "Sulphur Trade", 1:40-41.

30 DI 16:289 (15320000HAF00); DI 16:290 (15320718GRI00); DI 16:295 (15320823HAM01), 296 (15320901WIN00); Porsteinsson, "Island”, 182; Karlsson, Iceland's 1100 Years, 125; Aðils, Monopolhandel, 18-19.

31 "in quodam portu uocato Grenwyck ubi nulle Bremenses uel Hamburgenses naues eo tempore erant”. DI 16:315 (15330200HAM01).

32 DI 12:323. 
which they left in Iceland. ${ }^{33}$ In the document, they state that their predecessors and relatives had sailed to Iceland as well, but had lost their ships during the siege of Bremen by imperial forces during the Schmalkaldic war in 1547, after which Hamburg merchants had taken over, thereby suggesting that they had the right to use these harbours by tradition.

However, from the wording of the document it remains unclear which harbour these earlier Bremen merchants used. The dating of these events in the mid-1560s might suggest that the Bremen merchants took advantage of the temporary absence of many Hamburg traders from Grindavík and Keflavík, as was the case with Eyrarbakki. However, the emphasis placed in the request on the licence for Keflavík might indicate that they most feared competition from Hamburg there. A Hamburg merchant did indeed receive a licence for Keflavík the next year, but to whom the licence for Grindavík was granted (assuming it was) is not known. Instead, in November 1571, Claus Lude from Bremen was granted a licence for Grindavík, suggesting that Bremen merchants lost access to Keflavík but remained active in Grindavík, and by extension that Hamburg merchants had probably not sailed to Gríndavík often before, as they did not try to re-establish their presence in that harbour after they sorted out their problems with the Danish king.

In February 1586, Bernd Osthoff from Hamburg received a licence for Grindavík. It is is probable that Bremen merchants had used the harbour prior to this year, ${ }^{34}$ as the request in 1586 does not speak about a renewal, and Bernd Osthoff does not appear in the records of the confraternity of St Anne earlier. In October 1592, a request was made for the renewal of the licence, but now Paul Barnefeld was to hold it, because Osthoff himself would not sail to Iceland anymore, though he would remain active in the trade as a partner from Hamburg. The licence was granted, with the added name of Hans Steinkamp. ${ }^{35}$ It may be that no ships sailed from Hamburg to Grindavík in 1591 and 1592, as Osthoff and Barnefeld do not appear in the donation registers in those years, and Hans Steinkamp only on a ship to Hólmur. Three years later, there is a request for the renewal of the licence for Hans Steinkamp, with Osthoff still being part of the company, and again in autumn of 1598. Paul Barnefeld seems to have left

33 "thom dele dorch geferlickheit der bosenn having". RAK D11, Pakke 25 (Suppl. II, 15); SAB 2-R.11.ff. (15660329BRE00).

34 Claus Lude died in Iceland on 3 June 1585, and was buried in the church on Helgafell, Snæfellsnes, as his gravestone attests. See Figure 4.11, Section 4.5.

35 RAK D11, Pakke 26 (Suppl. II, 18a) (15921022HAM00). 
the company at that point, as he is mentioned as a former licence holder. ${ }^{36}$ In December 1601, Steinkamp and Osthoff requested to sail one more year to Grindavik, even though their licence had expired, because the ship of skipper Hans Hare had wrecked near Helgoland on the way to Iceland, and therefore they could not trade that year. ${ }^{37}$ The request was probably not granted, as Copenhagen merchants are attested in Grindavík the following year; we do find Hans Steinkamp on a ship together with Andreas Wegener in 1602, which probably sailed to nearby Eyrarbakki, from where Steinkamp must have tried to reclaim some of his outstanding debts in Grindavík.

\subsubsection{Básendar}

Names in the sources: Bedtsand; Bothsandt; Borsann; Boteswane; Botsamhareve; Botyshawe; Bousann; Bussant; Paßanth; Posandh

Located in a bay with small skerries on the western tip of the Reykjanes peninsula, Básendar was a difficult harbour, especially when the winds were out of the west, and ships had to be moored to the skerries with iron rings. The trading station was in Danish times located on a low rock formation, surrounded by sand. This made the buildings vulnerable to spring floods: during a storm in 1799 all buildings were destroyed by the waves, and the site was subsequently abandoned. The remains of the trading station, including one of the mooring rings, are still visible and have been surveyed. ${ }^{38}$ It is not entirely clear whether this was also the site of the German merchants' trading station. Kålund mentions that during the Hanseatic trading period, a neighbouring harbour to the south, called Pórshöfn, was used, although it is unclear on which source this is based. ${ }^{39}$

Wedged between Grindavík to the south and Keflavík to the north (Figure 6.2), Básendar covered only a small district with few inhabitants, yet it was one of the most important harbours for the winter fishing around Reykjanes. In a list of ten harbours offered to Hamburg in 1565, it is the second largest, requiring 30 lasts of flour annually, half the amount of Hafnarfjörour (Table 5.2). German merchants

36 RAK D11, Pakke 26 (Suppl. II, 18b): requests of 23 June 1598 (15980623HAM00); 25 July 1598 (15980725HAM00).

37 RAK D11, Pakke 26 (Suppl. II, 18b) (16011213HAM00).

38 Ragnheiður Traustadóttir, "Fornleifaskráning á Miðnesheiði / Archaeological Survey of Miðnesheiði”, Rannsóknaskýrslur 2000 (Reykjavík, 2000), 18-49.

39 Aðils, Monopolhandel, 287-88; Kålund, Beskrivelse af Island, 1877, 1:35. Kålund most likely bases his claim on an event described in 1518 in Jón Egilsson's Biskupa-annálar, the veracity of which is questionable (see below). 
must have realised its potential at a very early stage, and it is therefore the first harbour that we know to have been used by the Germans, namely by Hamburg merchants in $1423 .^{40}$

Básendar was not surprisingly the site of frequent clashes between English and German traders. In 1477 merchants from Hull complained about interference by the Germans; ${ }^{41}$ in 1491 the English complained during negotiations in Antwerp that two ships from Hull had been attacked in Straumur by 220 men from two Hamburg ships lying in Básendar and Hafnarfjörður; ${ }^{42}$ in 1497 a skipper from Hamburg allegedly denied an English ship access to Básendar; ${ }^{43}$ in 1509 skipper Cordt Froudendal from Hamburg encountered interference from the English; ${ }^{44}$ and Jón Egilsson recorded in the Biskupa-annálar that in 1518, Germans from Vatnsleysa, Keflavík, Básendar, and Pórshöfn had killed 40 Englishmen in Hafnarfjörður. Whether or not the latter event took place is doubtful, however, because there is no mention of it in contemporary English or German sources; the annals were written in the early seventeenth century. ${ }^{45}$ The violence of 1532 between the Germans and English erupted in Básendar as well, when Hamburg skipper Lutke Schmidt denied access to the harbour to the English ship Anna of Harwich. The arrival of another English ship a few days later caused tensions to spike, resulting in a battle in which two Englishmen were killed. Two months later, the conflict would spread to Grindavík.

The events of 1532 marked the end of the English presence in Básendar, and we hear little about the harbour in the years afterwards. The trading station seems to have been steadily frequented by Hamburg ships, sometimes as many as two per year. It could be that this was typical, with one ship mooring in Básendar and the other in Pórshöfn. In 1506 Hans Tappe from Hamburg stated that he could not trade in Básendar in some years before because another Hamburg ship was already there, suggesting that there was room only for one ship in the harbour of Básendar itself. ${ }^{46}$

40 HR III, 7, no. 455, §14, 15; DI 9:77 (15210919BRU00): English complaint from 1521 about interference in their activities in Básendar in 1423. The veracity of the source is questionable, however. See Section 3.4.1.

41 Ibid.

42 DI 11:43; HR II, 2, no. 511 §25 (14910610ANT00).

43 DI 11:46; HR II, 4, no. 14 §14, 15 (14970626ANT00).

44 DI 16:245 (15090814HAM00).

45 Karlsson, Lifssbjörg Íslendinga, 302, after Porsteinsson, Enska öldin, 247. See also DI 16, p. 509; Skúlason, "Hafnarfjörður", 189-191, who mentions that the annals were "of course a bit exaggerated in certain points", but believes that they are generally useful.

46 DI 16:257; SAH 111-1 Islandica, vol. 1a (15060100HAM00), in DI wrongly dated as 1516. 
Hamburg merchants continued to assert their right to the sole use of Básendar even after Iceland was leased to Copenhagen: in 1548 they refused to allow a Danish ship to enter the harbour. ${ }^{47}$ Hamburg merchants lost de facto control of Básendar for roughly two decades beginning in 1565, when Andres Godske and Knut Pedersen from Copenhagen received a licence for the harbour, followed by Copenhagen burgomaster Marcus Hess in June 1566; the latter complained about Hamburg interference in Básendar in $1570 .{ }^{48}$ It is unclear how long Hess was active there; in 1572 he received licences for harbours in the north, although this does not necessarily mean that he ceased trading in Básendar.

From 1583 onwards, Hamburg merchants were continuously active in Básendar again until the introduction of the Danish trade monopoly. In March 1584, three men from Wilster in Holstein, downstream from Hamburg on the Elbe, were issued a licence for Básendar and Pórshöfn, but they do not seem to have used it. A ship from Hamburg is registered each year from 1583 onwards with Jurgen Grove, Jurgen Schinckel, and Reimer Ratkens on board. These three men also held licences for the harbour from 1586 onwards.

The last evidence we have of a German presence in Básendar provides valuable details about the workings of the trade in Iceland. In 1602, when Ratkens' licence had expired, Danish merchants from Copenhagen concentrated their activity in Keflavík and Grindavík. A ship from Helsingør, with on board Hamburg merchant Johan Holtgreve, a crew largely consisting of Dutchmen, and helmsman Marten Horneman from Hamburg, tried to reach Skagaströnd in northern Iceland, but was unable to because of the great amount of sea ice. They therefore went to Básendar, which was not in use at the time. However, the Copenhagen merchants, claiming that Básendar belonged to Keflavík and Grindavík, protested. King Christian IV later ordered the Hamburg city council to confiscate the goods from the returned ship, upon which a document was produced in which the merchants and crew members told their side of the story. According to them, they had been welcomed by the inhabitants of the district of Básendar, who had trouble selling their fish because the catch had been bad the previous year and the fish were so small that the Danish merchants did not want to buy them. Moreover, most of their horses had died during the winter, so they could not transport the fish to Keflavík or Grindavík, and the Danes would not come to them. ${ }^{49}$ It is the case that at first Danish merchants were not eager to trade in

47 Aðils, Monopolhandel, 33.

48 RAK D11, Pakke 26 (Suppl. II, 16) (15710324FRE00).

49 RAK D11, Pakke 27 (Suppl. II, 19): documents from August/September 1602 (16020800KOB00, 16020806KOB00, 16020912HAM00, 16020830HAM00). See also Sections 3.5.6 and 4.1.2. 
Básendar, and did not sail there until they moved their business from Grindavík in $1640 .^{50}$

\subsubsection{Keflavík}

Names in the sources: Kebelvig; Keblewig; Kibbelwick; Kibleweich; Kieblewigk; Kippelwick; Kiæbleviig

Like the other harbours on the tip of the Reykjanes peninsula, Keflavík was predominantly a fishing settlement, and its district was relatively small with few farms, covering roughly the coast of the bay of Stakksfjörour. In the list of harbours offered to Hamburg merchants in 1565, Keflavík is characterised as a mid-sized harbour, requiring 20 lasts of flour each year, a third of the amount for Hafnarfjörður (Table 5.2). According to Kålund in 1877, the Hanseatic merchants had their booths on a small island facing the cliff Hólmsberg, just north of the current town of Keflavík, the ruins of which were allegedly still visible at the time. ${ }^{51}$

We hear little about Keflavík in the late fifteenth and early sixteenth centuries. None of the episodes of conflict between the English and Germans that characterise this period in the other harbours on the peninsula are known from Keflavík. In 1518 the harbour is mentioned as a site for German merchants in the Biskupa-annálar, but as noted above this entry is questionable. ${ }^{52}$ Trading in the harbour was almost without exception undertaken by merchants from Hamburg, of whom the first certain mention in the donation register is in $\mathbf{1 5 4 5 .}$ It could be that the harbour was not used before the 1540s, but this is unlikely, given the great significance of the other harbours in Reykjanes.

The only times we hear of merchants from other cities, i.e. of Bremen, are during periods when Hamburg merchants were not allowed to sail to Iceland. In 1565, Herman Schomaker and Herman Krechting from Bremen requested a licence for it, together with Grindavík. They indicated that Bremen merchants had sailed to the area before 1547, but it is unclear which harbour they meant by this. ${ }^{53}$ In the case of Keflavík, their request was turned down, as a licence was granted to Joachim Thim from Hamburg in June 1566.

In 1580 we find the first mention of Hans van Hutlen on a ship to Keflavík. He would acquire a licence for the harbour in 1586, and renew it every three to

50 Aðils, Monopolhandel, 287-288.

51 Kålund, Beskrivelse af Island, 1877, 1:32; Aðils, Monopolhandel, 289-290.

52 See Section 6.2.3 (Básendar).

53 See Section 6.2.2 (Grindavík). 
four years until the introduction of the Danish monopoly. The first year in which Danish merchants were active in Keflavík was 1602. Where the history of trading in Keflavík had been relatively peaceful, the end was quite turbulent, as the German merchants hurriedly tried to finish their business in Iceland while their licences were still valid. In 1602 the merchants in Hafnarfjörður rented a space of 50 lasts on a ship in Keflavík for the sum of 750 mark. This space was probably intended for goods to be transported from the harbours in Straumur and Vatnsleysa, which was shared between the merchants in Keflavík (one-third) and Hafnarfjörður (two-thirds). Danish merchants complained that the German presence in Keflavík was illegal and requested Hamburg's city council to confiscate the goods of the ship when it returned in autumn, but Hans van Hutlen and his companions responded that they were sailing on the licence for Vatnsleysa and Straumur, which was valid for two more years. ${ }^{54}$ Meanwhile, the Hafnarfjörður merchants refused to pay the freight money, as they claimed that the Keflavík merchants, after they had loaded their own goods in Keflavik, had arrived in Hafnarfjörður but had stayed very far out at sea and for no longer than about 30 hours, and furthermore had used a portion of the reserved space, so that the Hafnarfjörður merchants could not transport all of their cargo. ${ }^{55}$

\subsubsection{Vatnsleysa / Straumur}

Names in the sources:

Vatnsleysa: Wadtloß, Wattloes; Wattlose

Straumur: le Streyme, Stroem, Ströme

Vatnsleysa and Straumur are two small bays between Keflavík and Hafnarfjörður (Figure 6.2) that were used irregularly by German traders, as they are located too close to the latter to be of particular interest. In 1588, Vatnsleysa was characterised in a document from Bremen as "not a separate harbour, but only a minor place on a beach". ${ }^{56}$ Only Straumur, close to Hafnarfjörður, seems to have been a harbour of some importance during the English period. In many of

54 RAK D11, Pakke 27 (Suppl. II, 19): complaint from Copenhagen merchants, August 1602 (16020800KOB00, 16020806KOB00); answer from Hamburg, September 1602 (16020913HAM00, 16020916HAM00).

55 SAH 111-1 Islandica, vol. 4: documents about the case, which was dealt with by the city council, 1602-1604 (16021021HAM00, 16021126HAM00, 16030400HAM00, 16030429HAM00, 16030505HAM00, 16040111HAM00, 16040123HAM00).

56 "Wattloße inndt sudenn, so im gleichenn keine sonderbare having, dann einn geringer ordt eins sehstrandes seinn soll”. SAB 2-R.11.ff.: instruction for Heinrich Bredelo (15880118BRE00). 
the documents about the clashes between English and German merchants in the late fifteenth and early sixteenth centuries, English ships are mentioned as having been in Straumur. One of the reasons they used this harbour was to trade in sulphur from the nearby mines in Krýsuvík. ${ }^{57}$

Concerning the later history of both harbours, the above-mentioned document produced in the course of the complaints about Hamburg merchants in Keflavík submitted by Copenhagen merchants in 1602 provides a good deal of information. The Hamburg merchants set forth an overview of those who had sailed to the two harbours from 1573 onwards until the start of their licence in 1596 to counter the Copenhagen merchants' claims that no German had used them before: ${ }^{58}$

1577: merchants from Hamburg and Buxtehude in Straumur

1578: a merchant from Buxtehude in Vatnsleysa

1580: Folckert Frese from Hamburg in Straumur

1582: Jurgen Reinstorp from Hamburg in Vatnsleysa

1583-84: a merchant from Bremen in Vatnsleysa

1585: Hinrick Schutte from Hamburg and the ship of Duke Adolf of HolsteinGottorp in Straumur

1589: a merchant from Hamburg in Straumur and one from Bremen in Vatnsleysa

1591: Matthias Vlenhop from Hamburg in Straumur; a merchant from Bremen in Vatnsleysa

The merchant from Bremen in both 1589 and 1591 was Johan Schroder, who applied for a licence of the harbour in September 1589, under the pretence that he had sailed there for a couple of years before. ${ }^{59}$ The licence was granted for three years. If we assume that the list above is complete, he might have used it irregularly, but it is likely that he sailed there much more often, and probably until 1595.

57 Mehler, "Sulphur Trade”, 196. Baasch, Islandfahrt, 107, identifies "Strome” as Straumfjörður, near Borgarfjörður south of Snæfellsnes (Figure 6.2). This is unlikely, given the frequent mention of "Strome" in combination with "Wattlose" (Vatnsleysa), which suggests that the harbours were in close proximity to each other. However, in the seventeenth century the inhabitants of Borgarfjörður regularly asked that a ship sail to Straumfjörður, as had been the case when Hamburg merchants traded in the area (Aðils, Monopolhandel, 294). This suggests that Hamburg merchants were indeed sailing there in the sixteenth century, although there is no contemporary evidence to support this.

58 RAK D11, Pakke 27 (Suppl. II, 19) (16020913HAM01).

59 RAK D11, Pakke 26 (Suppl. II, 16) (15890000BRE00); Pakke 24 (Suppl. II, 9) (15890915EUT00); SAB 2-R.11.ff. (15890906BRE00, 15890906BRE01). 
Indeed, the request for the combined licence for Vatnsleysa and Straumur, which the Hamburg merchants were granted in February 1596, seems to have been an attempt to eliminate competition from Bremen from their districts. The licence was given to Rotman Pöner, Cordt Wemeyer, Jacob Hambrock, and Herman Kopman. The latter three were merchants in Hafnarfjörður and Keflavík, and the first was the son of Fritz Pöner, the Danish toll collector in Rendsburg. The four men did not fit out a ship themselves, but rented space on the ship of the merchants in Keflavík. ${ }^{60}$ As we saw above, this was a collaboration between merchants from Hafnarfjörður and Keflavík. In a letter from Danish merchant Niels Busk to Fritz Pöner in January 1596, the former warned the latter that his son should be quick to apply for a licence, as Bremen merchants were also applying for one. In passing he mentioned that he had also applied for a licence for Straumur himself. ${ }^{61}$ This suggests that the project in both harbours was an attempt by Hamburg merchants, in cooperation with Danish partners, to cut out the Bremen competition in their district. Successfully at first, the project ended in conflict, which has been sketched above. ${ }^{62}$

\subsubsection{Hafnarfjörður}

Names in the sources: Haffnefiordt; Hahnenfurdt; Hamsfurth; Hanefiordt; Hanenforde; Hanefur; Hanefürth; Haneviore; Hanevoort; Hauesford

If there is one place frequented by German merchants in the fifteenth and sixteenth centuries that had the potential to become a permanent German settlement or Kontor in Iceland, it would have been Hafnarfjörour, at least in the 1530s. The harbour exceeded all other harbours in Iceland in terms of trade volume, number of merchants, and political importance. Hamburg merchants usually sailed here with two ships a year, with more merchants travelling than on any other route. 50 to 60 persons per ship were not unusual, whereas the ships to Keflavík, usually only one per year, had about 40 on board each year, the other harbours even fewer. ${ }^{63}$ The list of harbours offered to Hamburg in 1565 lists Hafnarfjörður as requiring 60 lasts of flour each year, double the amount of Básendar, the second harbour on the list (Table 5.2). As described in more detail

$60 \mathrm{SAH}$ 111-1 Islandica, vol. 4: statement of the licence holders, 13 September 1602 (16020913HAM00).

61 RAK D11, Pakke 24 (Suppl. II, 9): Aarhus, 14 January 1596 (15960114AAR00).

62 See Section 6.2.4 (Keflavík).

63 See Section 7.4.4 and Figure 7.3. 
above, Hamburg merchants built a church here in the 1530s, which seems to have functioned as the social centre of the Hamburg merchants in Iceland, or at least in the Southwest. ${ }^{64}$

In terms of commodities, Hafnarfjörður was an important harbour for stockfish as well as for other products, and it is characterised as both a fish and slaughter harbour during the Danish trade monopoly. It seems that many farmers from southern Iceland brought their produce here instead of to Eyrarbakki. ${ }^{65}$ During the period of German dominance, the trading region for fish seems to have spanned a large stretch of coast, roughly the southern part of Faxaflói bay, with the exception of the region near Keflavík. As Skúlason notes, the licence for Hafnarfjörður for Joachim Wichman in 1566 explicitly prohibited the sulphur trade, whereas the licence for Keflavík for Joachim Thim in the same year did not, indicating that sulphur might have been traded in Hafnarfjörður as well. ${ }^{66}$ This is not unlikely, given the proximity to the Krýsuvík area, and the fact that nearby Straumur had been used as a harbour for sulphur export by the English before (Figure 6.2).

A leading factor contributing to Hafnarfjörður's prominence was that it was one of the few secure harbours in southwestern Iceland. The trading site was located in a bay on the northern coast of the Reykjanes peninsula, specifically on an islet called Háigrandi, which was connected to the shore by a natural stone causeway, Hvaleyrargrandi. This provided a natural sheltered harbour that could be defended easily and ships could be loaded quickly (Figure 6.3). ${ }^{67}$

Curiously, there are hardly any references to the harbour before 1400. It is first mentioned in the Icelandic annals when Norwegian merchants visited the harbour in 1391. During the fifteenth century, it became a major harbour for the English, but it also attracted Dutch and German merchants. In 1413, Icelandic annals mention an English merchant named Richard, who first landed in Eyrarbakki, went on to Skálholt, and afterwards sailed to Hafnarfjörður to trade, probably because Eyrarbakki was a notoriously difficult harbour. The first mention of a German ship is from 1471, when a ship from Holland, having arrived in Hafnarfjörður and discovered that the English had captured a German ship, subsequently drove away the English and freed the Germans. ${ }^{68}$ The first certain evidence for Hamburg merchants in Hafnarfjörour is in 1486,

64 See Sections 5.4.3 and 7.1.1.2.

65 Aðils, Monopolhandel, 291-292.

66 DI 14:329 (15660303FRE00); Skúlason, “Hafnarfjörður”, 216.

67 Guðmundsson, Saga Hafnarfjarðar, vol. 1, 12-14.

$68 H R$ II, 7, no. 39, §30. See Section 3.3. 


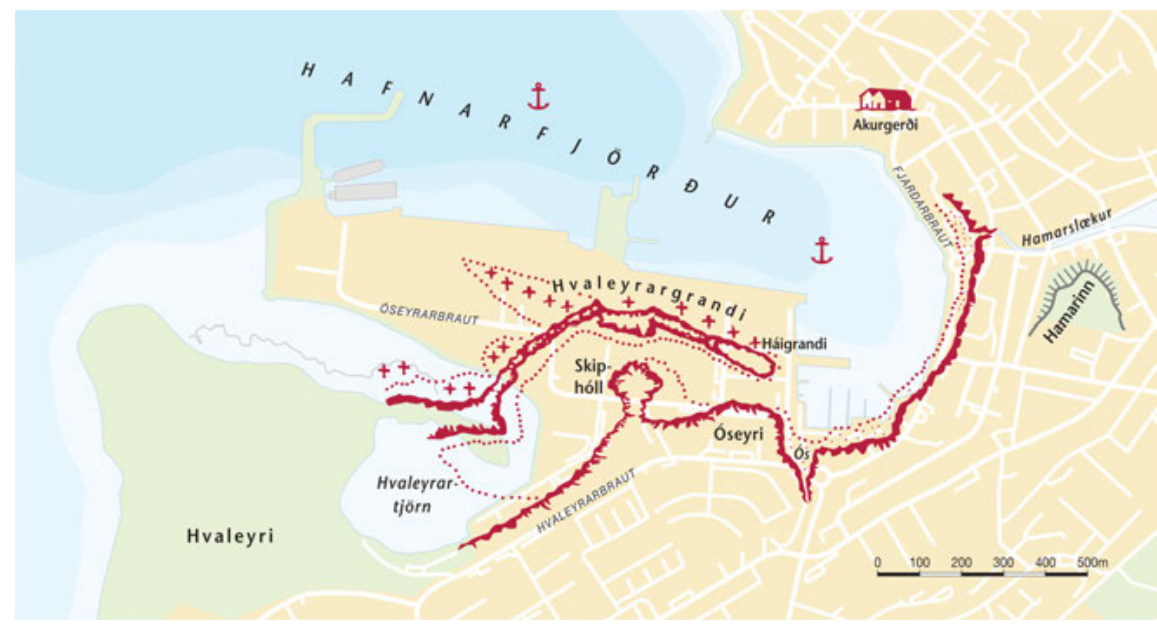

Figure 6.3: Map of the modern harbour of Hafnarfjörður with an overlay of the historical coastline (red). The trading site was located on Háigrandi. Map courtesy of Gudmund O. Ingvarsson.

when Lutke Sten arrived here in his $\operatorname{cog} .{ }^{69}$ Around this time, Hamburg merchants must have out-competed the English, who apparently moved their business elsewhere. $^{70}$ It is significant that the clashes between the English and Germans in Iceland (except for the 1471 case sketched above) frequently involved merchants from Hafnarfjörður, but almost never took place in Hafnarfjörður, with nearby Básendar and Grindavík being the sites of conflict.

Another decisive factor for the importance of Hafnarfjörður was its nearness to some of the centres of political power on Iceland: the royal farm at Bessastaðir, residence of the Danish governors and bailiffs of Iceland in the sixteenth century, was located on a headland just north of the harbour; and pingvellir, the place of the annual assembly at the Althing, was located about $40 \mathrm{~km}$ inland. The diocese of Skálholt was a bit closer to the harbour of Eyrarbakki, but Hafnarfjörður had the advantage of being a considerably better harbour, as the account of the English merchant from 1413 shows.

The close relations of the merchants in Hafnarfjörður with the officials in these places are indicated by many sources. Merchants from Hafnarfjörður showed up at

69 DI 16:294 (15320000HAM00). According to the Hamburg pound toll register, the ship was owned by Eler van Stendelen and left Hamburg between 30 April and 13 May: Hormuth, Jahnke, and Loebert, eds., Pfundgeldlisten, 182. A return journey is not attested in the same year. 70 Skúlason, “Hafnarfjörður”, 180-93; Porláksson, “Urbaniseringstendenser”, 179-180. 
the Althing on various occasions, and a copy of the 1527 verdict of Althing, which was signed by the governor as well, was drafted in Hafnarfjörður. ${ }^{71}$ Merchants from Hafnarfjörður allied with bailiff Didrick von Minden (whose brother was one of the Hamburg merchants) in the battles with the English in 1532. And when the governor Lorentz Mule tried to limit the influence of German merchants in Iceland in the years 1548-1550, many of the negotiations and conflicts took place in

Hafnarfjörður. ${ }^{72}$ Lawmen, governors, and bailiffs are also frequently mentioned in the donation register of the confraternity of St Anne on ships from Hafnarfjörður. It is therefore not hard to understand why Skúlason characterises Hafnarfjörður as "a kind of capital [. . .] for all of Iceland" for the German merchants. ${ }^{73}$

Hafnarfjörður always seems to have been an exclusive domain for Hamburgers, whereas Bremen and Lübeck traders were active in nearby Hólmur. Hamburg merchants even seem to have taken pains to prevent merchants of other cities from trading there: Lübeck merchant Herman Vurborn complained in 1539 that Hamburg merchants had prevented him from using the harbour, even though he had been given permission by King Christian III. ${ }^{74}$ The Hamburg merchants in Hafnarfjörður seem to have been a tightly knit community, one that is not hard to identify in the Hamburg donation registers each year. Where ships to other harbours often had different skippers each year, the same skippers sailed to Hafnarfjörður year after year, sometimes for decades. Some examples are Jurgen vam Hagen (attested in the years 1536-1553), Peter Korner (1536-1551), Herman Struckmeyer (1555-1572), Joachim Valeman (1559-1589), Herman van Schuren (1573-1583), and Hans Holtgreve (1587-1600). Moreover, the licences for Hafnarfjörður (always two at the same time from 1586 onwards) were mostly issued in the name of the skipper instead of the merchant leading the trading, as was usual in most of the other harbours. ${ }^{75}$

The pattern in the donation registers sketched above does not change much during the difficult years for Hamburg in the mid-1560s. Although the total number of ships to Iceland decreased sharply (Figure 3.4), ships to Hafnarfjörður are recorded every year. The only exception are the years 1576-1578, when Copenhagen burgomaster Marcus Hess held the licence for Hafnarfjörður, although one ship is recorded as sailing to Hafnarfjörður in 1577. This may have been requested by the Icelanders, who had complained at the Althing about the poor quality of the

71 Skúlason, "Hafnarfjörður”, 202-205.

72 Skúlason, 213-15.

73 Skúlason, 213-14.

74 SAH 111-1 Islandica, vol. 4 (15390000LUB00), vol. 2 (15390206LUB00); DI 10:112; Skúlason, 200. 75 See Section 7.2.3. 
commodities and about unfair trading practices in Hafnarfjörður in $1576 .{ }^{76}$ After 1578, licences for all Reykjanes harbours were issued to governor Johan Bockholt, ${ }^{77}$ who must have worked closely with the Germans, as business seems to have continued as usual in Hafnarfjörður, as well as in the other harbours. Moreover, Bockholt is sometimes mentioned spending to St Anne's confraternity.

Hafnarfjörður was one of the few harbours for which licences were still valid for two years after the Danish trade monopoly was introduced in 1601. The last years, however, were not easy for the German traders there. The Copenhagen merchants, who had started to trade in Keflavík and Grindavík in 1602, made life difficult for the Germans, and compounding the problems of the latter was the dispute with the Keflavik merchants about the transport of commodities from Vatnsleysa and Straumur, as sketched above. Moreover, they were pressed by the merchants in Hvalfjörður, who had lost their ship in the Elbe in 1601, to help them transport their commodities, which they refused to do. ${ }^{78}$ On top of that, the merchants were not allowed to enter into any new trading relationships. Unfortunately, the debt system made it almost impossible to trade without bringing in new customers via credit. ${ }^{79}$ The merchants in Hafnarfjörður must therefore have experienced considerable losses in these last years.

\subsubsection{Hólmur (Reykjavík)}

Names in the sources: Holmen; Bremer Holm

About $10 \mathrm{~km}$ north of Hafnarfjörður, the northern shore of the headland Seltjarnarnes near the farm Reykjavik housed the harbour known as Holm (Hólmur). It was named after a small tidal island, Grandahólmi, which could be reached at low tide over a natural stone causeway, not unlike Hafnarfjörður. Halfway between Grandahólmi and Seltjarnarnes, a second branch of the causeway led to the islet Örfirisey, which is nowadays in Reykjavík harbour. As we can see on a map from 1715, the Danish trading station was located on Örfirisey, with Grandahólmi only indicated as a group of insignificant skerries (Figure 6.4). Kålund mentions that there is a lot of evidence for the trading station originally being located on Grandahólmi and for ships anchoring in the bay Eiðisvik west of the causeway. The trading station was later moved to Örfirisey because of the

76 Skúlason, “Hafnarfjörður”, 222.

77 KB 1576-1579, 651.

78 SAH 111-1 Islandica, vol. 4: 28 February 1603 (16030228HAM00); RAK D11, Pakke 27 (Suppl. II, 19): 4 April 1603 (16030304HAM00).

79 Skúlason, “Hafnarfjörður”, 223-224. See Section 4.2.2. 


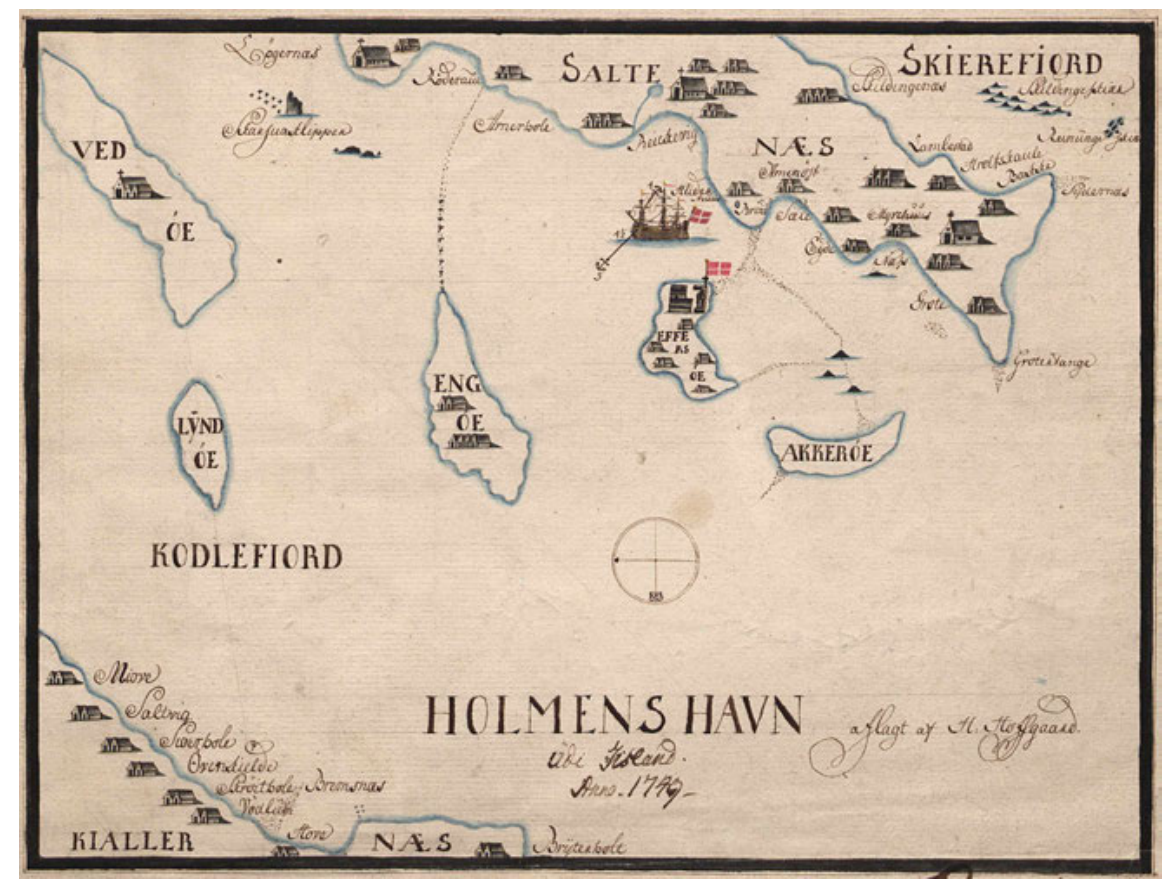

Figure 6.4: Map from 1749 of the Danish trading station in Hólmur, made by captain Hans Hoffgaard. The South is at the top. The trading station is indicated with a Danish flag on the island Örfirisey ("Effersøe”). Between Örfirisey, Akurey (“Akkerøe”), and the mainland Seltjarnarnes ("Saltenæs"), skerries are visible that represent the islet Grandahólmi, after which the trading station had been named earlier. (Copenhagen, Royal Library).

danger of storms and frequent flooding on Grandahólmi, with ships anchoring east of the island near Reykjavík, probably around 1700. None of this evidence, however, is contemporary. ${ }^{80}$ Travelling to both islets over the causeway was not without danger, and there were frequent mentions of accidents happening there. Around 1780, the trading buildings were moved to the mainland, and the harbour came to be known as Reykjavík after the farm. ${ }^{81}$

Hólmur was also frequently called "Bremer Holm", especially in the late sixteenth century. ${ }^{82}$ This is curious, because most of the documents about Hólmur

80 Kålund, Beskrivelse af Island, 1877, 1:5-7; 2:399-401.

81 Aðils, Monopolhandel, 292.

82 E.g. in the donation register SAH 612-2/5, 2 vol. 1 (15330000HAM00), f. 391v (1595), 414r (1598). 
in this period refer to merchants from Lübeck, notably Hans Delmenhorst, who was issued a licence for ten years in 1586, and Luder Ottersen. The identification with Bremen therefore relates to an earlier period. It is not unlikely that merchants from Bremen were the first to have used the harbour. The first reference to this is during the clashes with the English in 1532, when merchants from Básendar and Hafnarfjörður, "as well as the Bremen men (and) from Hólmur" helped the bailiff to defeat the English in Grindavik. ${ }^{83}$ In December 1548, six Bremen merchants complained to the city council that they visited the harbour every year, but that Herman Oldensche and some others, who had joined them for a couple of years, had invited a man from Lübeck (who would normally not sail there) to sail with them to Hólmur, and had violently driven their former associates out of the harbour. ${ }^{84}$ This was probably the end of Bremen presence in Hólmur. In the accounts of Eggert Hannesson from 1552, Lübeck skipper Henrick Kron is mentioned in Hólmur. ${ }^{85}$ In 1589, the widow of Lübeck merchant Hans Delmenhorst claimed that her former husband had sailed to Hólmur for about 35 years. ${ }^{86}$ If this is correct, he must have sailed for the first time in the mid-1550s. Therefore, around this time at the latest Bremen merchants must have lost the use of the harbour to Lübeck merchants. It might even have been the case that Herman Oldensche was a Lübeck citizen himself or had moved to that city. Roughly 20 years later, a Herman Oldenseel from Lübeck, who might have been the same person, acquired a licence for Vopnafjörður. ${ }^{87}$

The harbour Hólmur was a desirable trading site, and after Hans Delmenhorst died when his ship wrecked in the Elbe in 1589, both Peter Sivers from Hamburg ${ }^{88}$ and Carsten Bake from Bremen applied for a licence for the harbour. Although the licence for Delmenhorst was still valid until 1596, and his widow Anna requested to continue using the harbour, ${ }^{89}$ a new licence for three years was issued to Carsten Bake, possibly because Peter Sivers had already been granted a licence for Skagaströnd, for which he had also applied. However, this did not mean that the harbour was back in the hands of Bremen merchants. In the second year of his licence, Carsten Bake formed a maschup with Luder Ottersen from Lübeck, who

83 "ock dem Bremeren unde uth dem Holme wolden bystant dhon", as the Hamburg skipper Hinrick Berndes, who had been in Básendar himself, testified in 1533. DI 16:322 (15330210HAM01). The addition "unde" is puzzling here, leaving room for the possibility that the Bremen merchants were not trading in Hólmur but elsewhere.

84 SAB 2-R.11.ff. (15481209BRE00).

85 DI 12:323; Bei der Wieden, “Lübeckische Islandfahrt”, 17. See Table 5.1.

86 RAK D11, Pakke 28 (Suppl. II, 22) (15891028LUB00).

87 See Sections 6.6.1 and 7.2.6.

88 RAK D11, Pakke 26 (Suppl. II, 18a): 26 August 1589 (15890826HAM00, 15890826HAM01).

89 RAK D11, Pakke 28 (Suppl. II, 22): October 1589 (15891028LUB00, 15891030LUB00). 
had become Danish factor in Lübeck. According to Bake, he (Bake) had been forced to do so by governor Lorentz Kruse. ${ }^{90}$ Upon the latter's request, and after Ottersen had complained that Bake had sailed to England and stayed there for a year and had not behaved cooperatively, Bake left the harbour to Ottersen, ${ }^{91}$ who was granted the licence in his own name for three years in November 1592. In March 1599, a new licence for three years was issued for Ottersen and Jasper van Doren. The holder of the licence for the intervening three years is not known, but it is likely to have been Ottersen.

Although the trade in Hólmur was nominally always in the hands of Bremen or Lübeck merchants, Hamburg merchants did have a strong influence here, especially in the later sixteenth century. The ship of Hans Delmenhorst is attested in the donation register of St Anne's confraternity on multiple occasions, first in $\mathbf{1 5 7 0}$ and every year from 1581 onwards. Delmenhorst probably sailed to Iceland from Hamburg and returned there (which is also suggested by his shipwreck in the Elbe), and might have partnered with the Hamburg merchants. ${ }^{92}$ The same goes for Luder Ottersen's ship, which is attested in the register in 1591, indicating that Ottersen sent his own ship when Carsten Bake stayed in England that year. Jasper van Doren was also a Hamburg merchant, previously active in Hafnarfjörður, and mentioned as being on board the ships to Hólmur from 1592 onwards. Hólmur appears in the register regularly even after the introduction of the Danish trade monopoly, indicating that Hamburg skippers continued to sail there, probably having been contracted to do so by Danish merchants.

\subsubsection{Hvalfjörður / Akranes}

Names in the sources:

Hvalfjörður: Hvalfiordt; Wahlforede; Walforde haven; Wallefiord

Akranes: Ackernesse; Ackernisse; Arckermisse; Ackrannes

The fjord Hvalfjörður, north of Hafnarfjörður and Reykjavík (Figure 6.2), seemed to have belonged to the trading district of the latter harbours, as was the case during

90 RAK D11, Pakke 25 (Suppl. II, 15): complaint of Carsten Bake, 28 February 1593 (15930228BRE01); Pakke 26 (Suppl. II, 18a): winter 1592/3 (15921231BRE00).

91 RAK D11, Pakke 26 (Suppl. II, 18a): 1 October 1592 (15921001VIS00); Ottersen's request for a licence, 1593 (15930000XXX00).

92 The request of Peter Sivers for the harbour in 1596 (RAK D11, Pakke 26 (Suppl. II, 18a) 15890826HAM00) even states that Hans Delmenhorst was from Hamburg, which was probably a rhetorical trick to heighten the chances of receiving the licence. 
the Danish monopoly. ${ }^{93}$ Although Hvalfjörður was a major harbour for Norwegian merchants, who are first mentioned in the annals as being here in 1341, it lost importance after 1400 when Hafnarfjörður became established as the region's main trading site. ${ }^{94}$ This did not change during the German period, so that the inhabitants must have travelled south to Hafnarfjörður or Reykjavík to sell their produce. Only in the late 1540s, when Iceland was enfeoffed to Copenhagen, do we find mentions of Hamburg merchants in Akranes, on the headland at the entrance of the fjord. Heinrich Kopman is recorded as having sailed to Akranes in 1548 in the donation register of St Anne's confraternity and was probably active there until 1551. A complaint written around 1549 mentions that fish were confiscated from Kopman by governor Lorentz Mule..$^{95}$ This indicates that the use of Akranes may have been an attempt of Hamburg merchants to circumvent the limitations that were imposed by the Copenhagen-appointed governor on the German trade by moving their business from Hafnarfjörður to an unused harbour. It does not seem to have been used much in subsequent years, although Akranes was also mentioned in the list of harbours offered to Hamburg in 1565. Here it was the smallest harbour, requiring only ten lasts of flour annually (Table 5.2).

In November 1600, Hamburg merchants acquired a licence for Hvalfjörður ("Walforde") upon request of the inhabitants, who had found that Hafnarfjörður was too far away. ${ }^{96}$ However, the enterprise met with no success. The first ship that sailed to Hvalfjörður in 1601 wrecked on the return journey, on which occasion the licence was lost as well. ${ }^{97}$ The Danish king, who had announced the Danish monopoly in the meantime, was not willing to issue a new licence, and the merchants in Hafnarfjörður were not eager to help their colleagues as well, ${ }^{98}$ so German commercial activity in Hvalfjörður probably remained restricted to this one year.

Fieldwork at the archaeological site of Búðasandur or Maríuhöfn in the middle of the fjord on its southern shore, which was the trading site used by the Norwegians in the fourteenth century, did not reveal any building activity after $c$. $1490,{ }^{99}$ so either the German merchants in Hvalfjörður in the late sixteenth century used another trading site such as Akranes, which would mean that both names were used synonymously by the Germans, or they set up tents and did not

93 Aðils, Monopolhandel, 293.

94 Porláksson, “Urbaniseringstendenser”, 177-178.

95 SAH 111-1 Islandica, vol. 2 (15490000HAM00); Baasch, Islandfahrt, 106n2.

96 RAK D11, Pakke 24 (Suppl. II, 8): list of licences, 1601-1603 (16010000XXX00).

97 RAK D11, Pakke 27 (Suppl. II, 19): request for a copy of the licence (16021127HAM00).

98 SAH 111-1, vol. 4: complaints from the merchants, 28 February 1603 (16030228HAM00); April 1603 (16030400HAM01).

99 Gardiner and Mehler, "Trading and Fishing Sites”, 413-414. 
erect (semi-)permanent structures (which is not unlikely, given their short presence there). The latter possibility gains support from an overview of licences in which "Wallefiord" is mentioned as being located in "Kioß süßel" (Kjósarsýsla). ${ }^{100}$ This refers to the southern shore of the fjord only, whereas the northern shore, including Akranes, was part of Borgarfjarðarsýsla.

\subsection{Western Iceland: Snæfellsnes}

\subsubsection{Búðir}

Names in the sources: Badenstett; Berenstet; Bodenstede; Budenstede; Buderstadt Located on the southern coast of the Snæfellsnes peninsula around the mouth of the River Búðaós, Búðir was a trading site that in Danish times was associated with a large region mostly to the east. The reason that Búðir, which was also known as a slaughter harbour in Danish times because of the many farmers in its district, was located at the edge of the district, was possibly because the Germans who first started sailing here were mainly interested in fish, which were abundant around the tip of the peninsula (Figure 6.5). A fishing settlement was located on the western shore of the river, the ruins of which are still visible, whereas the

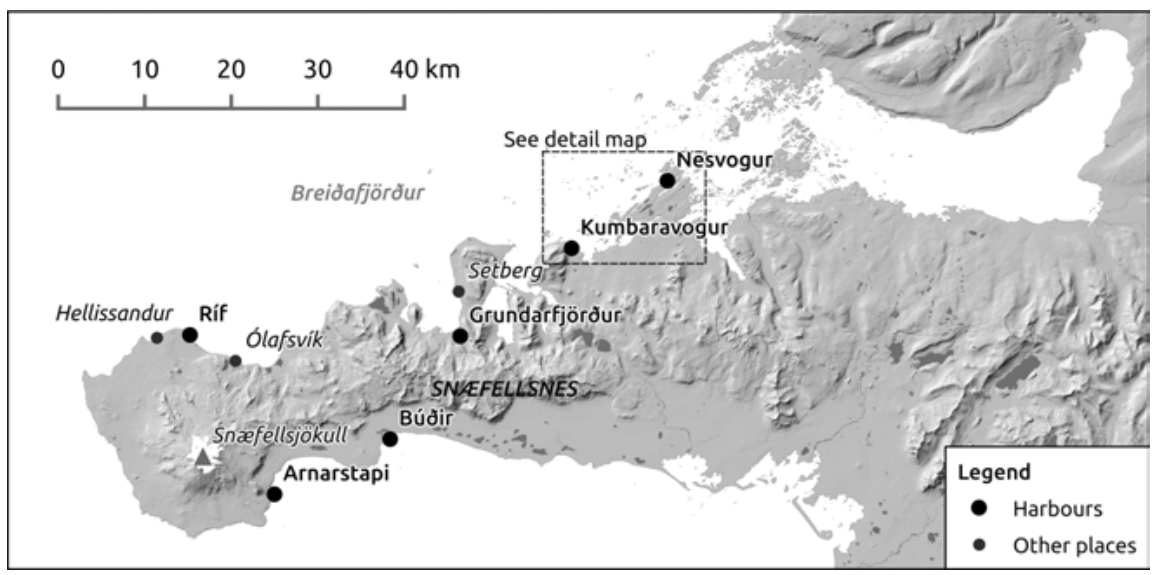

Figure 6.5: Map of trading stations and other locations in Snæfellsnes. See Figure 6.11 for the detail map of the area around Nesvogur and Kumbaravogur, see Figure 6.1 for location.

100 RAK D11, Pakke 24 (Suppl. II, 8): overview of licensed harbours, 1601 (16010000XXX00). 


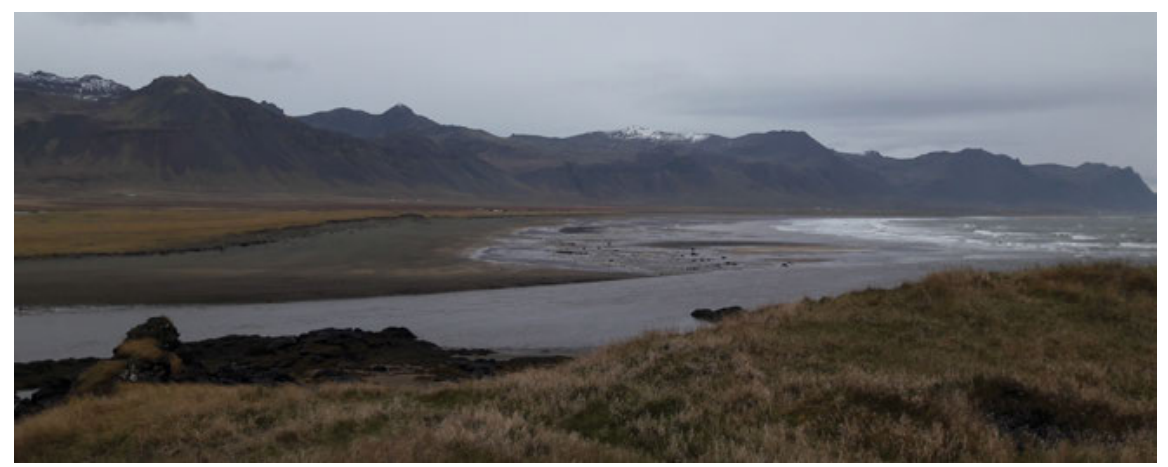

Figure 6.6: Búðir as seen from the west, with the River Búdaós in the foreground. The photograph is taken on the site of the fishing station, whereas the trading site was located on the beach on the opposite riverbank. Photograph by the author.

trading booths (after which the site is named) were located on the beach east of the mouth of the stream until the end of the eighteenth century (Figure 6.6) ${ }^{101}$ The harbour of Búðir, located at the mouth of the river, could only be entered at high tide and was quite dangerous. There are frequent mentions of wrecks here in German and Danish times, including that of the ship of Bremen merchant Vasmer Bake in the 1580s. ${ }^{102}$

For most of the sixteenth century, Búðir was frequented by merchants from Bremen. According to a document from 1588, it was first visited by Wilcken Hudeman in 1526, and was used continuously from then onwards. ${ }^{103}$ This is corroborated by a document from 1564, where it is stated that Bremen merchants had been visiting the harbour for about 40 years. ${ }^{104}$ The latter document was a complaint about the attempts of Hamburg skipper Jurgen Borchers to trade in Búðir that year, which was probably caused by Hamburg ships being prohibited from sailing to the nearby harbours Rif, Arnarstapi, and Grundarfjörður in $1563 .{ }^{105} \mathrm{Just}$ a few years later the Bremen merchants found themselves barred from visiting

101 Kålund, Beskrivelse af Island, 1877, 1:411-412.

102 RAK D11, Pakke 25 (Suppl. II, 15): letter of 28 February 1593 (15930228BRE01). Carsten Bake mentioned in 1593 that his father Vasmer had 'recently' ("vor kurtzen") lost his ship in the harbour of Búðir, and another ship had been taken by English pirates. The latter incident took place in 1587 , so it is likely that the shipwreck dates to the 1580 s as well.

103 SAB 2-R.11.ff. Instruction for Heinrich Bredelo, 18 January 1588 (15880118BRE00).

104 SAB 2-R.11.ff., RAK D11, Pakke 25 (Suppl. II, 15): 28 August 1564 (15640828BRE00).

105 DI 14:207, 209-11, 231; RAK D11, Pakke 25 (Suppl. II, 15): 20 December 1564 (15641220HAM00). The same thing happened in Kumbaravogur (see Section 6.3.5). 
Búðir as well by the Danish king, when a licence was granted to Danish counsellor Birge Trolle in February 1566. ${ }^{106}$ The Bremen envoy Tyleman Zerneman was sent to Denmark the next year to discuss, among various matters, the problems in Búðir and Kumbaravogur, ${ }^{107}$ and apparently was received favourably, as in October 1567, Bremen merchant Johan Hudeman (Wilcken's son?) received a licence for Búðir with no set term. Zerneman's instruction also indicates that Arnarstapi was considered as belonging to Búðir, but the licence does not mention this explicitly, which caused conflict some years later (see below). In Búðir, however, Hudeman remained active until the introduction of the Danish trade monopoly.

\subsubsection{Arnarstapi}

Names in the sources: Arenestappen; Stapfe; Stappe; Stoppen

Arnarstapi is located a few kilometres west of Búðir, just south of the volcano Snæfellsjökull (figure 6.5). The coast is rugged and is marked by cliffs: there is no natural harbour and ships had to anchor off the coast, unprotected from the weather. Despite this difficulty, Arnarstapi was sought after as a trading site because of the excellent fishing grounds around Snæfellsnes, especially in spring and winter. The trading site belonged to the royal farm of Arnarstapi, which was a seat of regional power at different points in time. ${ }^{108}$

A number of sources indicate that Arnarstapi was used for a long time, but its early history is hard to reconstruct due to the absence of clear statements in these sources. In 1591 Detmar Kenckel, Bremen factor for the Duke of BrunswickLüneburg, requested a licence for Arnarstapi, making the argument that his father, also called Detmar, had used the harbour for a long time before merchants from Hamburg took over. ${ }^{109}$ The elder Detmar Kenckel (1513-1584) had been burgomaster of Bremen, although it is unclear at which time he traded in Arnarstapi. Eggert Hannesson's 1552 accounts mention a Hamburg merchant in Arnarstapi, which provides us a terminus ante quem. ${ }^{110}$ Kenckel had started his commercial

106 DI 14:327 (15660228KOB00).

107 SAB 2-R.11.ff.: instruction for Tyleman Zerneman, 26 September 1567 (15670926BRE00).

108 Aðils, Monopolhandel, 296; Kålund, Beskrivelse af Island, 1877, 1:415-416.

109 RAK D11, Pakke 25 (Suppl. II, 15): 7 September 1591 (15910907BRE00).

110 DI 12:323 (see Table 5.1). In a letter to his wife from 1567, Detmar Kenckel wrote that he still had outstanding debts for the sale of Icelandic stockfish in Verden. Heinrich Smidt, "Aus Detmar Kenckel's Nachlass (Bremische Familienpapiere aus dem 16. Jahrhundert)”, Bremisches Jahrbuch 7 (1874): 30 . 
activities when he took over the business of his father, the burgomaster of Verden Dietrich Kenckel, upon the latter's death in $1531{ }^{111}$ It is unknown whether Detmar was already trading in Iceland at that time, but not impossible. In 1502, two German merchants in Iceland with the names Kinkel and Wilde are mentioned. ${ }^{112}$ The former may have been Dietrich Kenckel, and although the source does not mention a specific harbour, it is not impossible that he traded in Arnarstapi.

The Hamburg merchants took over trading in Arnarstapi in the 1540s. It is mentioned the first time in the donation register in 1561, but ships for previous years can be connected with reasonable certainty to the harbour from 1542 onwards. In 1563, however, King Frederick II banned the use of Arnarstapi, Rif, and Grundarfjörour to Hamburg merchants and granted the rights to these harbours to Danish citizens. The next year Bremen merchants complained about the interference of Jurgen Borchers from Hamburg in nearby Búðir. ${ }^{113}$ It is quite certain that these were the same Hamburg merchants who were trading in Arnarstapi before: in the donation register we find the merchants Asmus Stall and Hans Hase on the ship of Jurgen Borchers in 1563 and 1564. These merchants are also mentioned on the ships to Arnarstapi in 1561 and 1562.

In March 1565, a licence for Arnarstapi and Ríf was granted to Copenhagen merchant Andres Jude, although it is unclear if and how long he was active there. Johan Hudeman from Bremen, who had a licence for Búðir, complained in 1570 that Hans Gronewold from Hamburg had been using Arnarstapi for the last three years, even though his licence was for Rif only. Hudeman claimed that Arnarstapi was an emergency harbour (nothaven) belonging to Búðir (Figure 6.7). ${ }^{114}$ It is significant that from 1568 onwards, Asmus Stall, who is attested in Arnarstapi in the early 1560s, appears together with Hans Gronewold on ships to Rif in the Hamburg donation register. From 1573 onwards, the two are listed on separate ships, suggesting that Stall had started sailing to Arnarstapi again.

Once again the Hamburg merchants were not left in peace. In 1576 Arnarstapi and Rif were licensed to Richard Wederbar from Helsingør for three years, and afterwards to Copenhagen burgomaster Marcus Hess (together with Grundarfjörður). Both Wederbar and Hess encountered difficulties and Hamburg merchants must have profited from this. At least the Hamburg donation register suggests that Hamburg merchants were sailing to Arnarstapi from 1578 onwards,

111 Karl H. Schwebel, “Kenckel, Detmar”, Neue Deutsche Biographie, 1977, https://www.deut sche-biographie.de/pnd119727641.html\#ndbcontent.

112 DI 8:76; DN 16:338 (15020300LUB00).

113 See Section 6.3.1 (Búðir).

114 SAB 2-R.11.ff.; RAK D11, Pakke 25 (Suppl. II, 15): 23 January 1571 (15710123BRE00). 


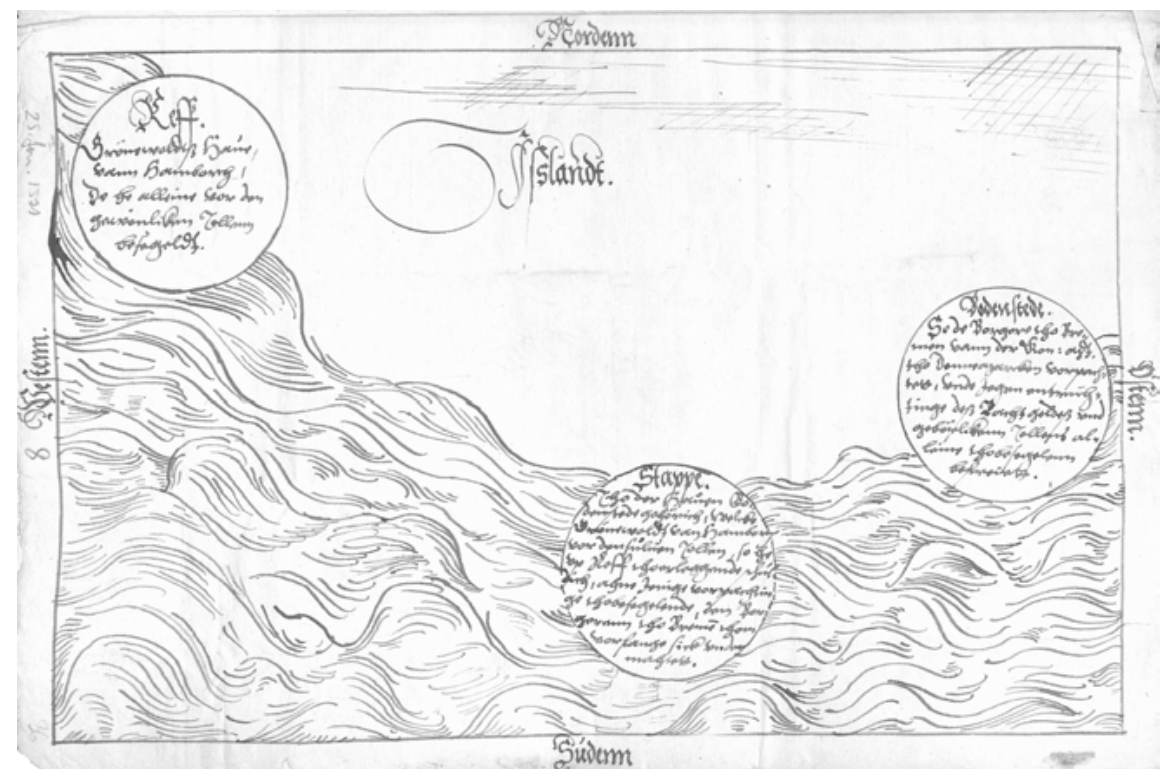

Figure 6.7: Drawing of the harbours around the tip of Snæfellsnes, accompanying Bremen complaints in 1571. Left to right, Ríf, Arnarstapi, and Búdir. RAK D11, Pakke 25 (Suppl. II, 15).

as the later licence holder Ambrosius Loring is attested in those years. This coincides with the capture of Richard Wederbar's ship by the English the year before. ${ }^{115}$ Marcus Hess, moreover, got into financial trouble in 1580, so that he must have been unable to continue his Icelandic business. ${ }^{116}$ In February 1586, Ambrosius Loring was granted a licence for Arnarstapi, which was renewed regularly until the Danish trade monopoly. Loring probably did not sail to Iceland himself after 1594, as Berndt Lininck and Jurgen Wegener are mentioned as merchants on the ships to Arnarstapi from then on.

\subsubsection{Ríf}

Names in the sources: Gambylweke; Gammelwick; Grannelwick; Reff; Reven; Reffuit; Reiff; Revet 
The harbour Rif, located on the northern side of Snæfellsjökull between various fishing settlements such as Hellissandur and Gufuskálar (Figure 6.5), was one of the best for the fish trade, and therefore the English, who called it Gammelwick, were active here as early as the fifteenth century. ${ }^{117}$ Ríf was a fairly secure harbour, but due to it silting up, the Danes moved the trading station to Ólafsvík, a bit further east, in the late seventeenth century. ${ }^{118}$ German activity in Ólafsvík is not known; although frequent requests were made to use Ólafsvík and Hellissandur west of Rif in the late sixteenth century, licences for those places were never granted. $^{119}$

The English seem to have been active in Rif / Gammelwick until the 1520s, when they were out-competed by Hamburg merchants, and moved to Grundarfjörður, east of Riff. In 1528, Hamburg merchants complained that the ship of Hans Schomaker, which was lying in Rif, had been attacked by seven ships from England. ${ }^{120}$ And in 1531, Hans Huge from Hamburg went to Ríf, when an English ship came from Grundarfjörour and bought all the fish destined for him. ${ }^{121}$ From this point on, the harbour was used by Hamburg merchants for a long time. In the Hamburg donation register, we find the ships of Hans Huge until 1545, and afterwards the merchants on his ship mostly sailed with Herman Struckmeyer. In 1549, we find Hans Gronewold on board Struckmeyer's ship for the first time; Gronewold would become the leading merchant of the Rif trade in the middle of the century.

From 1563, the history of Rif is closely intertwined with that of Arnarstapi, as has been sketched above. After a short period in which the harbours were licensed to Danish merchants, Hans Gronewold appears in the donation

117 DI 16:258 (15310523XXX00). Gamlavík is the name of a bay a bit further to the east, in which Ólafsvík is located. According to Aðils, Monopolhandel, 299, "Gammelwick" was therefore Ólafsvík. In English complaints from 1533 (DI 16:315), Hamburg skipper Hans Huge is mentioned as having been in "Gambelwyke", while German sources name the harbour he used as "Reff", indicating that both names were used for Rif. It is also possible that the harbours were not demarcated that precisely before the introduction of licences, and that both "Reff" and "Gammelwick" roughly meant the area around Rif and Ólafsvik, which after all are located very close to each other.

118 Aðils, 298; Kålund, Beskrivelse af Island, 1877, 1:420n2.

119 Requests of Carsten Bake for Hellissandur or Nesvogur, 1592: RAK D11, Pakke 26 (Suppl. II, 18a) (15921231BRE00); Herman Beverborch for Hellissandur, 1597: Pakke 27 (Suppl. II, 18b) (15970115HAM00, 15970118HAM00); Bernd Salefeld the Younger for Hellissandur or Ólafsvík, 1600: Pakke 27 (Suppl. II, 19) (16001113HAM00) and with his brother Henning, 1601 (16010213HAM00, 16010216HAM00); the Count of Oldenburg for Ólafsvík, 1603: NLO Best. 20, -25, no. 6 (16030200OLD01).

120 DI 16:294; SAH 111-1 Islandica, vol. 1a (15320000HAM00, 15280000HAM00), DI 11:96 (15280916HAM00).

121 DI 16:258 (15310523XXX00). 
registers of St Anne's confraternity again in 1566. His licence for Ríf, about which Bremen merchants wrote in their complaints concerning his allegedly illegal presence in Arnarstapi, ${ }^{122}$ was therefore most likely acquired in 1566. After being licensed to Danish merchants Richard Wederbar and Marcus Hess in the 1570s, Rif was visited by Hamburg merchants again around 1580, this time with Bernd Salefeld as the main merchant. He acquired a licence in 1586, and renewed it every three to four years. That said, there was a lot of competition among Hamburg merchants for the use of the harbour. Hans Hase requested a licence as well in December 1589, under the pretext that it could be used by two ships at once. The licence was issued, and then cancelled when Salefeld objected. ${ }^{123}$ When Salefeld died in December 1596, Joachim Terminau, who had been in service of the Danish king as translator, requested a licence, as did Herman Beverborch, who hoped to form a maschup with Salefeld's heirs. ${ }^{124}$ However, it was Bernd Salefeld the Younger who continued the business of his father, though only for three years. In January 1600, Rif was licensed to Bergen merchant Gerd Melsow. Salefeld, however, managed to acquire a licence for Flatey in Breiðafjörður, and stationed his brother David in Ríf in 1601. Because Salefeld did not manage to reach Rif in 1602, he returned in 1603 to collect his outstanding debts. However, by that time his licence for Flatey had ended as well, and his goods were confiscated by lawman Jón Jonsson, who accused David Salefeld of having been there illegally. There is no evidence that Bernd's repeated requests to the Danish court that his goods be returned to him were were successful. ${ }^{125}$

\subsubsection{Grundarfjörður}

Names in the sources: Grindfiordt; Grindeförde; Grindtvorde; Gronderforde; Grundefiort; Grundevorde; Grunfordt; Gryndeforde

The harbours located on the northern shore of the Snæfellsnes peninsula Grundarfjörður, Kumbaravogur, and Nesvogur - are among the best documented in the late sixteenth century, due to frequent disputes between merchants from Bremen and Oldenburg. The harbours were in demand because of the fish that

122 See Section 6.3.2 (Arnarstapi).

123 RAK D11, Pakke 26 (Suppl. II, 16): request (15891206HAM02); Pakke 28 (Suppl. II, 25): cancelled licence (15900129KOB02).

124 RAK D11, Pakke 27 (Suppl. II, 18b): request of Joachim Terminau, 24 December (15961224HAM00); of Herman Beverborch, 15 January 1597 (15970115HAM00). See also Section 7.2.1. 125 RAK D11, Pakke 27 (Suppl. II, 19): 8 September 1603-10 January 1604 (16030908HAM00, 16030913HAM00, 16030923HAM00, 16031113HAM00, 16040110HAM00). 
were caught in Breiðafjörður north of the peninsula (Figure 6.5), although their trading districts were small and sparsely populated. Grundarfjörður was in Danish times often combined with Kumbaravogur to the east. In 1662, the Danish trading site was moved from Kumbaravogur to Grundarfjörður (Figure 6.8). ${ }^{126}$ The trading site was located on the beach Grundarkampur on the southeastern shore of Grundarfjörður bay, a few kilometres east of the modern town. The trading site, the ruins of which are still visible, was also used by Dutch and French traders as late as the late nineteenth century. ${ }^{127}$

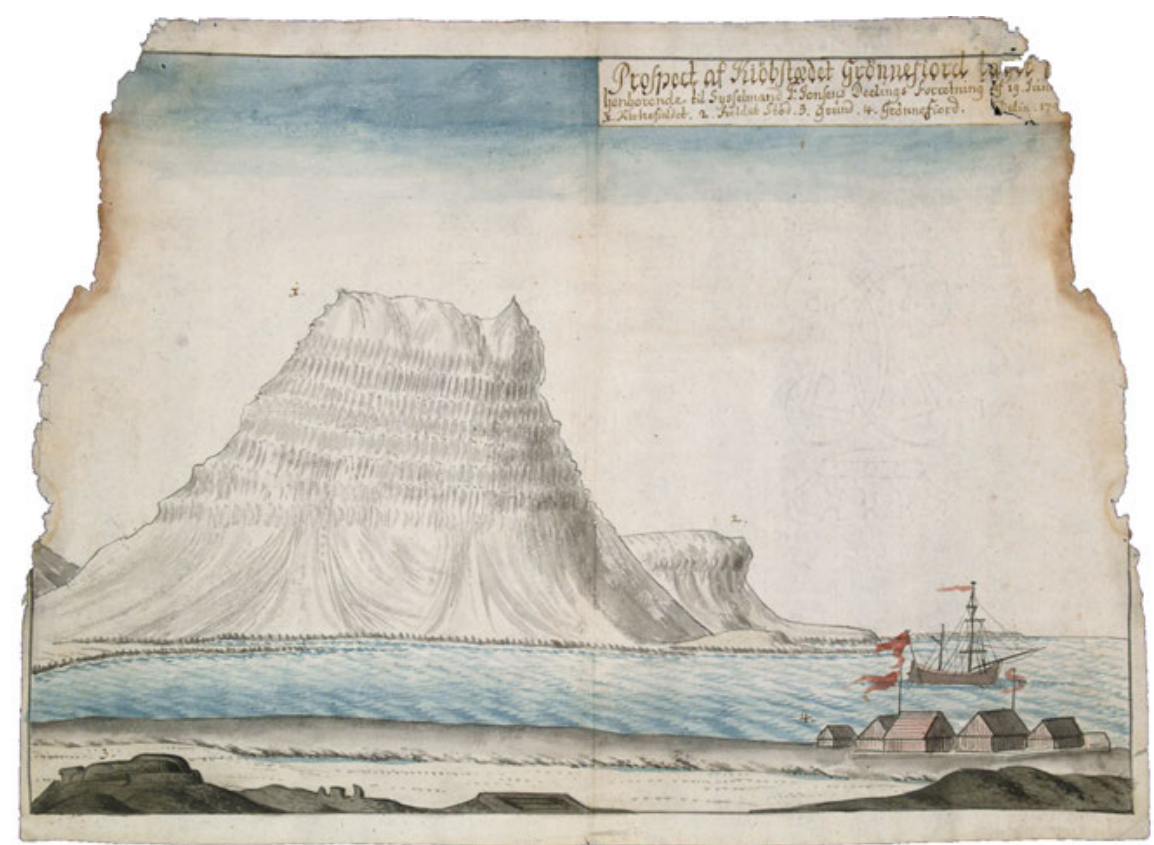

Figure 6.8: Drawing of the Danish trading station in Grundarfjördur by the priest Sæmundur Magnússon Hólm from Helgafell (1792) with the mountain Kirkjufell in the background. Image courtesy of Pjódskjalasafn Íslands, Reykjavík, Drawing Collection 5/5.

The first reference to a German presence in Grundarfjörður relates to a dispute between Hamburg merchants in 1506. A ship of skipper Lubberd Tideman had

126 Aðils, Monopolhandel, 300.

127 Kålund, Beskrivelse af Island, 1877, 1:427. It is not known whether the Germans also traded at this site. The ruins are all connected to the period after 1662. 
come to the harbour in 1504, three days after Hans Tappe, who would not allow the merchants to use the harbour and destroyed the booths while they were trying to build them. According to Tappe, however, it was custom that the first to arrive in a harbour had the exclusive right to use it, and he was therefore not obliged to allow others to trade there. ${ }^{128}$ A Bremen complaint from 1523 tells that Bremen skipper Hinrick Haneman, while on his way to Kumbaravogur, had been killed by Hamburg skipper Kersten Junge when the latter had attacked the former's ship to prevent him from going to Grundarfjörður. ${ }^{129}$ Several years later, Hamburg merchants seem to have switched harbours with the English in Rif: Hans Huge complained that English merchants from Grundarfjörður had taken his fish in Rif in 1531. The English, however, responded that they had gone to Grundarfjörður after they were expelled from Rif by Huge, and were attacked by men from Hamburg and Bremen, who threatened to kill them and stole their goods from their booths and weapons from their ship. ${ }^{130}$

Afterwards Hamburg merchants seem to have concentrated in Rif, and Grundarfjörour does not seem to have been used much. In the Hamburg donation register, the harbour is not explicitly mentioned until 1600. However, in the 1552 accounts of Eggert Hannesson (Table 5.1), skipper "Iorgen Meer" (possible Hinrick Meyer, according to the donation register) is mentioned in the harbour, ${ }^{131}$ and Hamburg merchants were prohibited from using the harbour as well as Arnarstapi and Rif in 1563. Afterwards, the Danes did not use the harbour as well, as Hans Gronewold, in applying (unsuccessfully) for a licence for Grundarfjörður and Arnarstapi, made the argument that the Danish merchants were only visiting Rif. ${ }^{132}$ It is also unlikely that Marcus Hess, who received a licence for the harbour together with Arnarstapi and Rif, made much use of the harbour, as has been sketched above. ${ }^{133}$ The same goes for the licence of archbishop Henry III of Bremen in 1584, which was for Grundarfjörður and Nesvogur together; the latter seems to have been used as the main harbour. ${ }^{134}$

From this moment at the latest, Grundarfjörður seems to have been regarded as a dependency of Kumbaravogur or Nesvogur/Stykkishólmur. The licence of Archbishop Henry was given to Count John VII of Oldenburg after his death in 1585, who also had a licence for Kumbaravogur. The account book of

128 DI 16:286, 287 (15060128HAM00, 15060100HAM00). See also Section 4.5.

129 DI 16:268 (15231103BRE00).

130 DI 16:315 (15330200HAM01).

131 DI 12:323 (see Table 5.1); SAH 612-2/5, 2 vol. 1 (15330000HAM00), f. 114v.

132 RAK D11, Pakke 26 (Suppl. II, 16): 21 December 1563 (15631221KOB00).

133 See Section 6.3.2 (Arnarstapi).

134 See Section 6.3.6 (Nesvogur). 
the Oldenburg merchants in 1585, however, only mentions Kumbaravogur and Nesvogur as trading places, suggesting that Grundarfjörður was not considered a separate harbour. ${ }^{135}$ The Danish king had a different opinion about this: when the Count requested a licence in 1596 for all three harbours, the king granted it, but for just two, as Grundarfjörður had been given to the Archbishop of Bremen John Adolf because the Oldenburg merchants did not use the harbour. ${ }^{136}$ Bremen merchant Hans Honne was probably trading in Grundarfjörður on behalf of the bishop at this time, as he is known to have requested permission to trade in Grundarfjörður or Landey in 1596 as well. ${ }^{137}$ In 1600, the last licence was given to

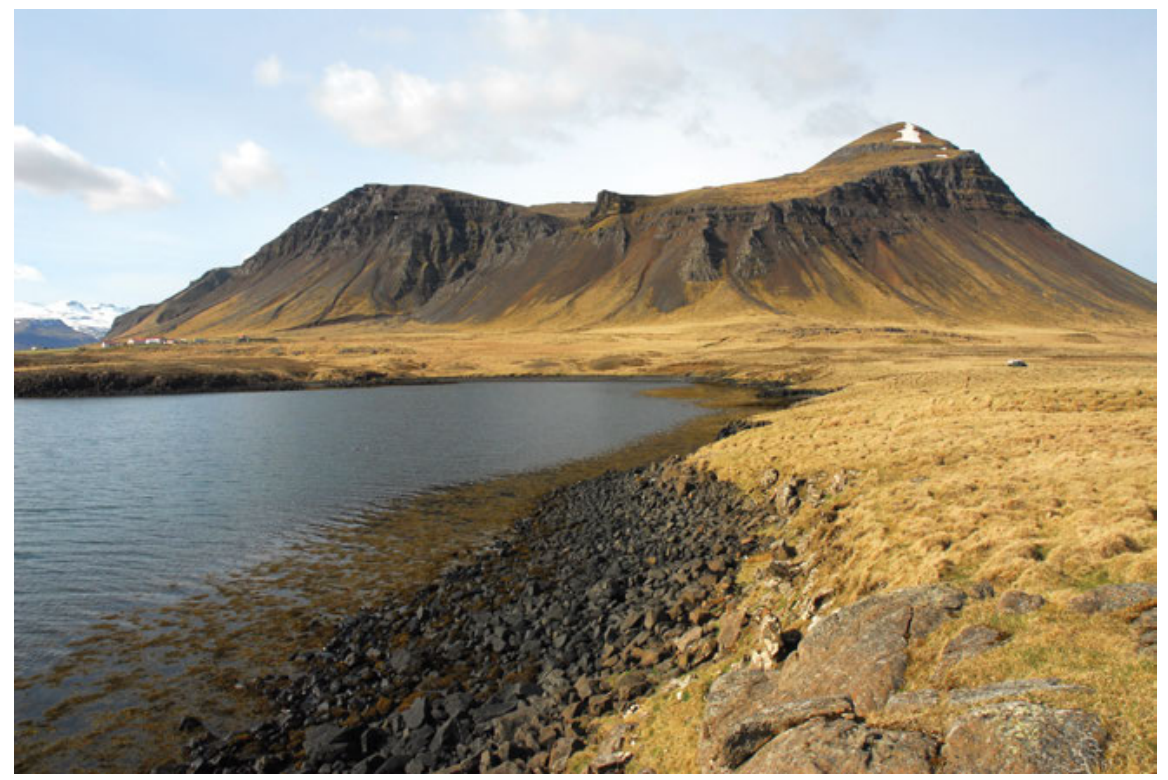

Figure 6.9: The bay of Kumbaravogur, looking towards the southwest from the trading site at Kaupstadartangi. Photograph courtesy of Natascha Mehler.

135 SAO 262-1, no. 2 (15850307OLD00).

136 NLO 20, -25, no. 6: request of the count, 19 February (159602190LD00); answer of the king, 29 March 1596 (15960329FRE00).

137 RAK D11, Pakke 25 (Suppl. II, 15) (15960000BRE00). Ásgeirsson and Ásgeirsson, Saga Stykkishólms, 111, mention that according to the Danish tax registers of governor Brostrup Gedde in 1596, a Johan van Lehe from Hamburg sailed to Grundarfjörður. However, there is no person with that name in the confraternity records, nor is there a ship to Grundarfjörður in the donation register in that year. It is possible that Gedde made a mistake here, and that the merchant was actually from Bremen. In 1600, sheriff Carsten Bake mentioned a Bremen merchant by the name of Hinrich von Lehe as being in Snæfellsnes (SAB 2-R.11.ff.: 16001230BRE00). 
Johan Harvest from Segeberg. He must have partnered with Hamburg merchant Herman Beverborch, who appears on ships to Grundarfjörður in the donation register during the three years that the licence was valid.

\subsubsection{Kumbaravogur / Landey}

Names in the sources:

Kumbaravogur: Cummerwag; Kombarewage; Kombarwoge; Kommerwoghe; Kummerwagen; Kummerwoghe

Landey: Landtoh; Landoch; Landog; Landöhe; Landø

Kumbaravogur on Snæfellsnes is a small bay located to the north of Bjarnarhöfn farm. A headland known as Kaupstaðartangi ('headland of the trading site') contains ruins of nausts (boathouses), a building, and an enclosure, which are believed to have been the trading site of German and Danish merchants. East of the bay there is a small tidal island called Landey, on which there are some more ruins, which are believed to be the trading site "Landoh" mentioned in some Bremen and Oldenburg sources at the end of the sixteenth century (Figure 6.10).

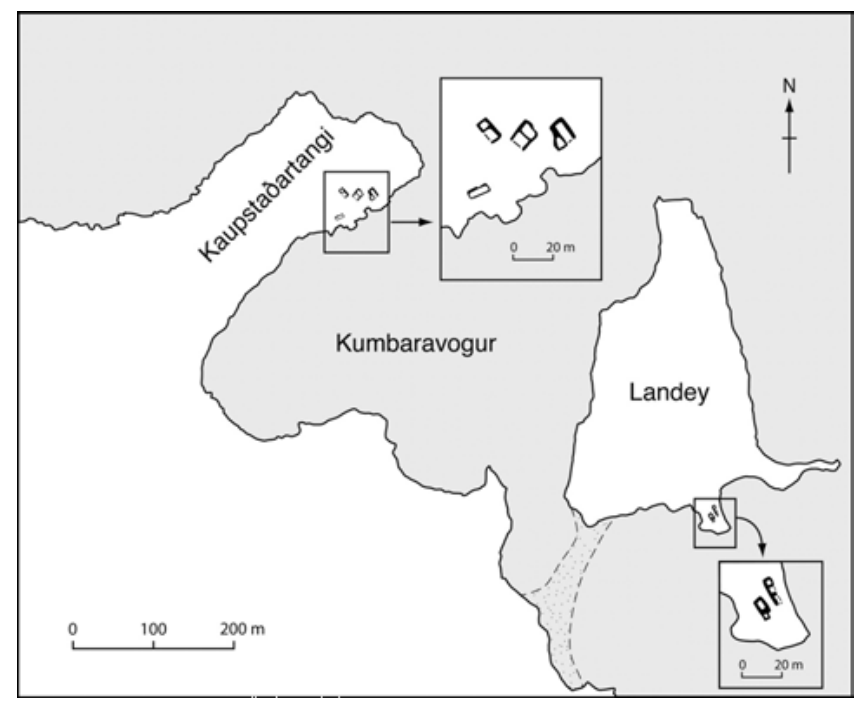

Figure 6.10: Map of the ruins of the trading sites in Kumbaravogur. Reproduced with permission from Mehler and Gardiner, "On the Verge of Colonialism”, 5. 
The site at Kaupstaðartangi was surveyed archaeologically, ${ }^{138}$ and in 2016 a trench was dug through one on the buildings at Landey, which revealed turf walls, a fireplace, and some ceramic fragments that could be dated to the sixteenth century. Analysis of the ceramics has shown that they were produced in the vicinity of Bremen, confirming the written evidence for Bremen and Oldenburg activity there. ${ }^{139}$

As indicated above, in Danish times Kumbaravogur was usually licensed together with Grundarfjörður or Stykkishólmur, and the trading site was moved to Grundarfjörður in 1662. In German times, Kumbaravogur was used as a trading site in its own right and seems to have been more important than Grundarfjörður and Nesvogur/Stykkishólmur, which were hardly used until the late sixteenth century. It was probably visited exclusively by Bremen merchants from the late fifteenth century on, as they claimed in 1564 to have used the harbour for almost 70 years. ${ }^{140}$ As we have seen, skipper Hinrick Haneman sailed to the harbour in 1522; the Bremen merchants who attacked the English in Grundarfjörour are very likely to have come from Kumbaravogur as well. ${ }^{141}$

In the 1560s, the merchants in Kumbaravogur were faced with the same problems as the Bremen merchants in Búðir, in the form of interference first from Hamburg merchants who were expelled from nearby Arnarstapi, Ríf, and Grundarfjörður in 1563, ${ }^{142}$ and subsequently from Danish counselor Birge Trolle, who received a licence together with Búðir in 1566. After Tyleman Zerneman pleaded their case at the Danish court, ${ }^{143}$ the harbour was returned to Bremen merchants, this time to Johan Munsterman, who received a licence in October 1567.

Bremen control of Kumbaravogur ended when Munsterman was beset with misfortune in 1576. In that year, his ship sank in the harbour during a storm. He and his partners acquired a new ship, but this one also wrecked on the return journey in the Weser river in 1578. Munsterman and 28 other men on board lost their

138 Gardiner and Mehler, “Trading and Fishing Sites”, 415-418.

139 The ceramics were analysed by Torbjörn Brorsson and Natascha Mehler, who were kind enough to share their preliminary results. Oldenburg merchants are known to have acquired most of their commodities for the Icelandic trade in Bremen: see Section 2.6.

140 SAB 2-R.11.ff.; RAK D11, Pakke 25 (Suppl. II, 15): complaint about Hamburg interference, 26 February 1564 (15640226BRE00).

141 See Section 6.3.4 (Grundarfjörður).

142 SAB 2-R.11.ff.; RAK D11, Pakke 25 (Suppl. II, 15): 26 February 1564 (15640226BRE00).

143 SAB 2-R.11.ff.: instruction for Tyleman Zerneman, 26 September 1567 (15670926BRE00). 
lives, and nothing of the cargo could be salvaged. ${ }^{144}$ Other persons involved in the enterprise found themselves in financial trouble because of the accident, such as Clawes Monnickhusen, who had borrowed money to freight Munsterman's ship and now could not repay what he owed. Thanks to this event, his account book is still extant, which probably ended up in the Bremen archive as evidence in the court case of his creditors against him. ${ }^{145}$ The account book lists where the customers of the merchants in Kumbaravogur lived in 1558, which gives us an impression of the extent of the trading district (Figure 4.4). This fits quite well with the statement from a document from 1567, in which the district of Kumbaravogur is described as reaching from Ríf and Ólafsvik to Flatey, ${ }^{146}$ with some customers even living outside this region.

Munsterman's widow and former companions requested permission to keep using the harbour, as they were afraid that competitors from Lübeck, Hamburg, or others from Bremen would take over. ${ }^{147}$ However, they lost the licence to a merchant called Joachim Kolling from the East Frisian village of Hooksiel, who was assisted in this matter by the Count of Oldenburg. ${ }^{148}$ Kolling had some years of experience in the Icelandic trade out of Hamburg and/or Bremen: in 1572 he shows up as servant and in 1577 as merchant on a Hamburg ship to Rif. ${ }^{149}$ Now he saw an opportunity to start his own business. He founded a trading company and chartered his brother-in-law, Bremen skipper Roleff Gerdes, to sail for him. The latter, however, was forbidden by the Bremen city council to sail for Kolling, on the penalty of being expelled from the city, probably after complaints from Munsterman's heirs. It is therefore likely that Kolling was not able to visit Kumbaravogur in $1580 .{ }^{150}$ In the meantime, the harbour was probably used by the Bremen merchants in nearby Nesvogur. In 1580, governor Johan Bockholt stated that Heine Ratke from Bremen had been trading in Kumbaravogur, although he

144 RAK D11, Pakke 25 (Suppl. II, 15): request from Munsterman's widow, 9 February 1579 (15790209BRE00).

145 Hofmeister, "Schuldbuch” (2001): 27. Monnickhusen (possibly his father) is first recorded in Kumbaravogur as a skipper in 1552: DI 12:323 (Table 5.1).

146 "von das Reff und Wyck bis Flattoy". SAB 2-R.11.ff.: instruction for Tyleman Zerneman, 26 September 1567 (15670926BRE00).

147 RAK D11, Pakke 25 (Suppl. II, 15): 9 February 1579 (15790209BRE00).

148 Kohl, “Oldenburgisch-isländische Handel”, 37; Ásgeirsson and Ásgeirsson, Saga Stykkishólms, 71-72. See Section 3.5.5.

149 SAH 612-2/5, 2 vol. 1 (15330000HAM00), ff. 228v, 249 r.

150 NLO 20, -25, no. 6; SAB 2-R.11.ff.: complaint from 6 April 1580 (158004060LD00); Kohl, “Oldenburgisch-isländische Handel”, 38; Ásgeirsson and Ásgeirsson, Saga Stykkishólms, 72-73. See Section 7.2.1. 
had no licence for the harbour. ${ }^{151}$ Ratke is mentioned as having been to Kumbaravogur some years earlier, where he had interfered in the business of Johan Munsterman, together with Dirick Vasmer, who had been in a harbour less than one hour sailing from Kumbaravogur. ${ }^{152}$ Dirick Vasmer is later mentioned in relation to Nesvogur, which is indeed very close to Kumbaravogur. (Figure 6.11) $)^{153}$

Kolling did not enjoy his licence for a long time. In 1585, the Count of Oldenburg requested a licence for Kumbaravogur in his own name, as well as for Nesvogur and Grundarfjörður, because Kolling had proved unreliable. ${ }^{154}$ The reason for the takeover was probably that Kolling got into financial trouble in 1583, and was unable to repay the money he owed to Luder Ottersen. ${ }^{155}$ The licence was granted in March, and the one for Nesvogur and Grundarfjörour in June, after the holder of the licence for the latter two harbours, prince-archbishop Henry III of Bremen, died in April. ${ }^{156}$ A new company was founded in Oldenburg and a ship bought in Emden, which was skippered by Clawes Kock. From the account books of the company we have a good overview of how this was organised. In 1585, the ship only sailed to Kumbaravogur (probably because the licence for Nesvogur and Grundarfjörður had not yet been issued at the time the ship left Oldenburg); the next year we find six merchants who were stationed in Kumbaravogur and another six in Nesvogur. ${ }^{157}$

The Oldenburg licences for Kumbaravogur were renewed a few times until the introduction of the Danish monopoly. During this entire period, however, Bremen merchants were able to retain their presence in the area by acquiring licences for harbours nearby. ${ }^{158}$ On the grounds that Oldenburg merchants had not visited

151 SAB 2-R.11.ff.: letter from Bockholt, 31 July 1581 (15810713BES00). Bockholt also stated that he had received a letter from Heine Ratke to his wife, in which Ratke had slandered Bockholt. The letter was brought to him by Kolling, who claimed that it was delivered to him by a schoolboy who found it in a Bremen alley, where it had been lost by Ratke's children who had been playing with it. Bockholt, however, did not believe this story and assumed that Kolling had found the letter in Roleff Gerdes's house and brought it to him in anger; Bockholt assured Kolling that the letter in no way influenced his attitude. This also shows that Kolling did sail to Iceland in 1581. See also Ásgeirsson and Ásgeirsson, Saga Stykkishólms, 73-74.

152 "nicht gahr eine stunde varendes von ihme gelegen". SAB 2-R.11.ff.: final plea of Bernd Losekanne against Christoffer Meyer (15760200BRE00).

153 SAB 2-R.11.ff.: complaints about Oldenburg merchants, 27 September 1583 (15830927BRE00).

154 NLO, 20, -25, no. 6; RAK D11, Pakke 25 (Suppl. II, 15): 13 February (158502130LD00).

155 See Section 7.2.6.

156 Ásgeirsson and Ásgeirsson, Saga Stykkishólms, 74-76.

157 SAO 262-1, no. 2 (15850307OLD00); Kohl, “Der oldenburgisch-isländische Handel”, 43-46.

158 See Sections 6.3.4 (Grundarfjörður), 6.3.6 (Nesvogur/Stykkishólmur), and 6.3.7 (Flatey). 
Kumbaravogur and Nesvogur in two years, Carsten Bake from Bremen requested and was granted a licence for Nesvogur and Landey in 1593. ${ }^{159}$ A dispute in Nesvogur in 1597, sparked by the Bremen merchants' claim that the single Oldenburg ship was too small to serve the needs of the local population, was probably the reason why Harmen Kloppenborg, the Oldenburg merchant, chartered the ship of Bremen skipper Dirick Walleman to sail with him to Kumbaravogur. However, the strategy backfired. In 1598, Kloppenborg sued Walleman for having secretly traded with his brother, who had been in a harbour nearby (probably Grundarfjörður or Stykkishólmur) and had allowed a load of stockfish to get wet, so that it spoiled. ${ }^{160}$ Finally, when the count requested a renewal of the licence for Kumbaravogur and Nesvogur in 1599, with an extension to Grundarfjörour and Landey, the extension was not granted because those harbours had already been given to someone else. ${ }^{161}$ In the case of Grundarfjörður, this was Johan Harvest from Segeberg, but it is unclear who was using Landey, as it is not mentioned in any licence at the time.

\subsubsection{Nesvogur / Stykkishólmur}

Names in the sources:

Nesvogur: Naßwage; Neschwagen; Neswag; Neßvoge; Nestwage

Stykkishólmur: Stichholm; Stickelshalm; Stikeshollm; Stickeningesholm; Styckingshölen

Standing on the former trading site of Kumbaravogur, one can see the presentday town of Stykkishólmur across the bay in the distance, which is only ten kilometres away (Figure 6.11). The settlement is located on the northern tip of the Grunnasundsnes peninsula, which is separated from the mainland of Snæfellsnes by a long and narrow bay, Nesvogur. This might be the bay that gave the name to the trading site known as "Neswage", although the bay seems too shallow for an ocean-going vessel to anchor in. The trading site was probably located on a small peninsula to the southwest of the town, called Búðanes ('headland of the booths'), where some ruins are located that might have been the trading booths of foreign merchants. The current harbour, located north of the town, might be the place known as a separate harbour, "Stickingsholm", in the late 1590 s.

159 RAK D11, Pakke 25 (Suppl. II, 15): request, 28 February 1593 (15930228BRE00). 160 NLO 20, -25, no. 6: report of the court case, 19 August 1598 (159808190LD00). 161 NLO 20, -25, no. 6: letter of Christian IV, 22 December 1599 (15991222KOB00). 


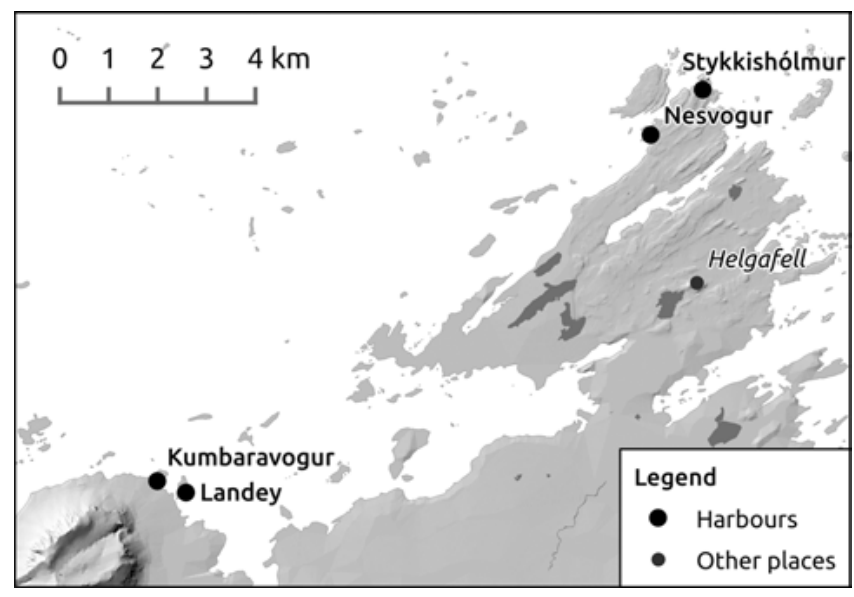

Figure 6.11: Map of the trading stations around Kumbaravogur and Nesvogur. See Figure 6.5 for location.

Although Stykkishólmur was an important settlement, in proximity to the fishing grounds of the many small islands in Breiðafjörður, the monastery of Helgafell, and the local thing site just south of the town, it was overshadowed by Kumbaravogur initially. ${ }^{162}$ The first mentions of foreign traders in the harbour Nesvogur are Evert Hoveman, Dirick Vasmer, and Hinrick Salomon from Bremen, who claimed in 1582 that they had sailed there for the first time seventeen years earlier, ${ }^{163}$ and the following year Hoveman and Johan Koster claimed that they had sailed there for the first time sixteen years earlier. ${ }^{164}$ This leads to the first visit being around 1566, when Birge Trolle was issued the licence for Kumbaravogur, so that Bremen merchants started to sail to Nesvogur when they were expelled from Kumbaravogur. They seem to have established a more or less permanent presence in Nesvogur, from where they maintained their ties with Kumbaravogur as much as possible. When Johan Munsterman's widow requested that she be allowed to continue sending a ship to Kumbaravogur in 1579, she mentioned Nesvogur as well. ${ }^{165}$

Though Nesvogur was not given to Joachim Kolling when he was granted the licence for Kumbaravogur, the merchants in Nesvogur feared that they would lose

162 Ásgeirsson and Ásgeirsson, Saga Stykkishólms, 17-63.

163 RAK D11, Pakke 25 (Suppl. II, 15): complaint from 13 February 1582 (15820213BRE00).

164 SAB 2-R.11.ff.: complaint from 27 September 1583 (15830927BRE00).

165 RAK D11, Pakke 25 (Suppl. II, 15): 9 February 1579 (15790209BRE00). 
their harbour should an accident occur, as had happened with Kumbaravogur. Their fear was not unfounded: when Dirick Vasmer's ship was damaged on the way to Iceland in 1583 and had to return to Bremen, the merchants asked the archbishop Henry III of Bremen to help them prevent someone else from taking over the harbour. ${ }^{166}$ However, the archbishop, who had applied unsuccessfully for a licence in Iceland earlier that year, was granted the licence himself instead, together with Grundarfjörður. ${ }^{167}$ He subsequently hired Bremen skipper Bruning Nagel to sail there for him. ${ }^{168}$ Of course the merchants in Nesvogur were not amused, and the Bremen city council decided in February 1585 that Johan Koster, Nagel, and Christoffer Meyer had to sail together, whereby Nagel would own a sixth part of their ship, and that they would have to buy a bigger ship next year. ${ }^{169}$ However, the Nesvogur soap opera was to be continued. In April the same year, archbishop Henry died, rendering his licence invalid. The merchants requested a new licence for themselves, not knowing it had already been promised to the count of Oldenburg, who had applied for a licence for Nesvogur and Grundarfjörður a few months before. ${ }^{170}$

Bremen merchants saw an opportunity to re-establish their presence in Nesvogur when Bremen merchant Carsten Bake was made sheriff of Snæfellsnes in 1593, after he had lost two licences in a row. ${ }^{171}$ Bake, who knew that the Count of Oldenburg had not renewed his licence after the death of King Frederick II, saw an opportunity and requested a licence for Nesvogur and Landey for himself, which was granted for three years in April 1593. He claimed in his request that Oldenburg merchants had not come to Nesvogur and Kumbaravogur for two years, ${ }^{172}$ which was probably true, ${ }^{173}$ as the Oldenburg merchants only complained

166 SAB 2-R.11.ff.: complaint from 27 September 1583 (15830927BRE00).

167 SAB 2-R.11.ff.: correspondence between Henry III and the Danish king, 1583/4 (15830612BRV00, 15830621HAD00, 15831024DRI00, 15840422BRV00, 15840503SKA00, 15840503SKA01).

168 SAB 2-R.11.ff.: declaration of Henry III, 10 August 1584 (15840810BRV00).

169 SAB 2-R.11.ff.: verdict of the Bremen city council, 3 February 1585 (15850203BRE00).

170 SAB 2-R.11.ff.: request from Bremen, November 1585 (15851122BRE00, 15851120BRE00; also in RAK D11, Pakke 25 (Suppl. II, 15); answer from Frederick II, 17 December (15851217KRO00).

171 See Sections 6.2.7 (Hólmur), 6.3.7 (Flatey), and 4.4.1.1.

172 RAK D11, Pakke 25 (Suppl. II, 15): 28 February 1593 (15930228BRE01).

173 Bremen merchants had complained in 1589 that no Oldenburg ship had visited Nesvogur in two years (SAB 2-R.11.ff. - 15890906BRE00). It seems that the Oldenburg merchants experienced major difficulties in organising the trade, and had financial troubles. At least one case in 1594 hints at this: after the death of skipper Clawes Kock, who owned a fourth part of the ship, Hamburg merchants Bernd Salefeld, (who traded in Ríf) and Daniel Moers, to whom he was heavily indebted, wanted their money back. The answer of the Oldenburg 
about the situation in August 1594, after more than a year had passed. Merchant Harmen Kloppenborg had come to Nesvogur that year and found Bremen merchant Hans Honne there, who had burned the booths of the Oldenburg merchants to the ground and denied Kloppenborg access to the harbour. ${ }^{174}$ The count complained to the king about the situation, and was told that he should have renewed his licence in time; however, he was promised that he would receive Nesvogur again once Bake's licence expired. ${ }^{175}$

To avoid losing their access to Nesvogur to Oldenburg again, Bremen merchants played another trick. With the help of Carsten Bake, Heinrich Alberts and Albert Kote received a licence in the winter of 1595/6 for the harbour Stykkishólmur, only $1.5 \mathrm{~km}$ from Nesvogur. The Oldenburg merchants complained that Stykkishólmur actually belonged to Nesvogur, whereupon the king cancelled the licence for Alberts and Kote. ${ }^{176}$ The latter then collected testimonies from inhabitants of the area, in which they stated that Stykkishólmur and Nesvogur were indeed two separate harbours. ${ }^{177}$ Moreover, other testimonies by the inhabitants claimed that the Oldenburg merchants did not bring enough goods, as they sailed with one ship of 40 lasts, whereas Evert Hoveman and Heine Ratke had always sailed with two ships of $c$. 50 fifty lasts each, and finally that the Oldenburg merchants had sold them bad flour mixed with clay. ${ }^{178}$ Although the last statement might have been a mean attempt to discredit the Oldenburg merchants, they do seem to have lacked the capacity and means to bring enough commodities for the district. This explains why the Bremen merchants were ultimately successful in retaining their presence in the area. After a failed attempt of the Oldenburg merchants to hire an additional ship from Bremen to sail with them to Kumbaravogur the next year, ${ }^{179}$ the Bremen licence for Stykkishólmur was renewed in September 1598.

Icelandic company (NLO 20, -25, no. 6 - 15941214OLD00) suggests that they did not have enough capital to repay what he owed. See Section 7.2.1.

174 NLO 20, -25, no. 6: anonymous complaint, 26 August 1594 (15940826OLD00).

175 NLO 20, -25, no. 6: 20 November 1594 (15941120FRE00); Ásgeirsson and Ásgeirsson, Saga Stykkishólms, 76.

176 NLO 20, -25, no. 6: March 1597 (15970300OLD00); 4 April 1597 (15970404KOB00).

177 NLO 20, -25, no. 6; SAB 2-R.11.ff.; RAK D11, Pakke 25 (15970716STY00, 15970708STY00).

178 NLO 20, -25, no. 6; SAB 2-R.11.ff.; RAK D11, Pakke 25 (Suppl. II, 15) (15970420BRE00, 15970614STY00, 15970725HEL00, 15971102BRE00).

179 See Section 6.3.5 (Kumbaravogur). 


\subsubsection{Flatey}

Names in the sources: Flattohe; Flatte; Flattoge; Flatøey; Flattöh; Flettoge; Flottog Flatey is a small (flat) island in the middle of the bay of Breiðafjörour (Figure 6.12). It was located on the border between the trading districts of Kumbaravogur/Nesvogur and of the harbours in Barðaströnd. A Bremen document from 1588 mentions that the licence Johan Munsterman held for Kumbaravogur granted him the right to trade in Flatey, which was "not a separate harbour, but just a small remote place on an island". ${ }^{180}$ Due to its remote location from the harbours mentioned above, it became a trading place in its own right in the 1580s and 1590s. The trade here was discontinued in Danish times, much to the disappointment of the locals. ${ }^{181}$

To the north of the island, the ridge of a crater sticking up out of Breiðafjörður provided a fairly secure natural harbour known as Hafnarey ('harbour island'). The trading site was initially on the northern side of Flatey, facing Hafnarey, in a bay called Grýluvogur. Between Hafnarey and Grýluvogur is an inlet that was known as Pýskuvör ('German landing place'), where the ruins of German buildings were allegedly still visible in the eighteenth century. ${ }^{182}$ North of Flatey, on the northern coast of Breiðafjörður on the peninsula Svínanes, there is a small bay called Kumbaravogur with ruins that are connected by local tradition to the presence of German traders (Figure 6.12). ${ }^{183}$ If this is correct, then this site must have been used by the merchants from Flatey, since there is no direct mention of the place in the written sources, and Flatey was the only harbour in the vicinity known to have been used by Germans.

Although quite a few sources mention Flatey, they provide conflicting accounts or are hard to interpret. Flatey is first mentioned when a licence for the harbour was issued to Lübeck merchant Hinrick Sluter in December 1579. Sluter does not appear in any other source, so it is uncertain whether the licence was ever used. In 1582, Carsten Bake from Bremen mentions that he had visited the

180 "so doch keine sonderbare havinge, dann alleinn einn kleinn abgelegenn ortt eines eillandts seinn soll”. SAB 2-R.11.ff.: instruction for Bremen ambassadors, 18 October 1588 (15880118BRE00). 181 Aðils, Monopolhandel, 303.

182 Kålund, Beskrivelse af Island, 1877, 1:540-541; Bjarni F. Einarsson, "Mjaltastúlkan î gígnum”, Árbók Hins íslenzka fornleifafélags, no. 90 (1993): 134; Gardiner and Mehler, "Trading and Fishing Sites", 408.

183 Mark Gardiner, Conor Graham, and Natascha Mehler, "Survey of Archaeological Remains at Svínanes, Reykhólahreppur, Iceland”, OITIS Field Report, no. 2, 2011. 
harbour, and that he had been there 30 years earlier; he states that it has been much improved in the meantime. ${ }^{184}$ The presence of Bake, who had been trading in Nesvogur before, suggests that the use of Flatey as a harbour seems to have been part of the attempts of Bremen merchants to retain their presence in the area around Kumbaravogur.

Bake's statements, however, are more confusing than enlightening. He also claimed to have received a licence for the island in 1583 for four years, and that he then lost the licence to an Icelander in 1588, which does not fit. ${ }^{185}$ A request of Hamburg merchants for a licence for Flatey in 1589 states that Bake first used the harbour in 1586, which makes the loss of the licence in 1588 plausible. ${ }^{186}$ If we accept Bake's statement that he visited Flatey for the first time in 1582, he must have traded there for a few years without a licence. The Hamburg request was denied because Bake received a prolongation of his licence on 12 September 1589, but on 25 September of the same year a licence was indeed issued to an Icelander, Páll Jónsson. Bake's licence was probably cancelled, since he was subsequently granted a licence for Hólmur. ${ }^{187}$

Páll Jónsson, interestingly, just three days after receiving the licence declared that he was partnering with a Bremen citizen called Björn Jónsson. ${ }^{188}$ It is not known who this person is. The name suggests an Icelander who had settled in Bremen, but it was not unusual for Germans to be referred to by a patronym in Icelandic sources. Aðils suggests that this was Bernd Salefeld, who would acquire the licence in October $1593 .^{189}$ It is unclear on what source Aðils based this claim: the 1593 licence only mentions the name Björn Jónsson. Moreover, Bernd Salefeld was from Hamburg and held a licence for Rif at the time. What does fit, however, is that both Björn and Bernd Salefeld died in 1596, after which the licence for Flatey was given to Danish merchants. In Ríf, the licence was taken over by Bernd's son, Bernd Salefeld the Younger, who interestingly received a licence for Flatey in 1600 after he lost access to Ríf. ${ }^{190}$

184 "Item yck Karsten Bake hebbe de havynge yn Yslant Flatto geheten vor erst myth minen lyve unde gude up gesegelt das do formalß yn 30 yaren mene Dydesche scheppe gelegen hebben unde iß nu van mynen yn segelen konincklyke moyestat syne armen under danen wol eyn grote vor betert geworden”. SAB 2-R.11.ff. (15820000BRE01).

185 RAK D11, Pakke 25 (Suppl. II, 15): letter of 28 February 1593 (15930228BRE01).

186 RAK D11, Pakke 26 (Suppl. II, 18a): request of 4 July 1589 (15890704HAM01).

187 See Section 6.2.7 (Hólmur).

188 RAK D11, Pakke 25 (Suppl. II, 15): statement of 28 September (15890928KOB00).

189 Aðils, Monopolhandel, 59 n. 3; See also Koch, Isländer in Hamburg, 271n13.

190 See Section 6.3.3 (Ríf). 
It is also difficult to figure out who was trading in Flatey after 1596. A note on the back of the 1593 licence mentions Niels Busk and Frederik Leyel from Helsingør as having an interest in using the harbour, and after a dispute arose between them in 1598, they asked a man from Bremen (probably sheriff Carsten Bake) to mediate. ${ }^{191}$ However, klaus Ericksen from Copenhagen is mentioned as holding the licence for three years in January 1596, and only two years after that a certain Johan Vogit from Bremen is mentioned as also holding the licence for three years. This only makes sense if Claus Ericksen was sailing on behalf of Busk and Leyel, and that the latter two ceased trading when they came into conflict in 1598. Johan Vogit also appears as a servant of the Danish factor Luder Ottersen from Lübeck in the latter's request for a licence for Hólmur in $1593,{ }^{192}$ but either the licence was not used or they ran into difficulties, as Bernd Salefeld the Younger was granted a licence for Flatey in 1600 before Vogit's licence had expired.

\subsection{The Westfjords}

The northwestern region known as Vestfirðir (Westfjords) relied heavily on fishing, which brought the region great wealth from the start of the fish export trade. A high density of fishing settlements on the many bays and harbours is attested, mainly in the fjords along the Greenland Strait and the southern fjords of Ísafjarðardjúp. ${ }^{193}$ Correspondingly, many harbours were used in the area in German and Danish times, which were roughly divided into two districts: a southern district around the fjords Patreksfjörður, Arnarfjörður, and the northern coast of Breiðafjörður, covering the sýsla Barðaströnd; and a northern one around Dýrafjörður and the bay Ísafjarðardjúp, covering Ísafjarðarsýsla (Figure 6.12). However, the many different trading places, and in extension, the many different names used for harbours and licences, complicate the identification of the harbours.

191 RAK D11, Pakke 24 (Suppl. II, 9): letter of 28 January 1598 (15980128VIB00).

192 RAK D11, Pakke 26 (Suppl. II, 18a) (15930000XXX00). See Sections 6.2.7 (Hólmur) and 7.2.6.

193 The fishing economy in this region is well known, due to the archaeological and historical work of Ragnar Edvardsson. See Edvardsson, “Commercial and Subsistance Fishing”, 49-67; "Marine Resources". 


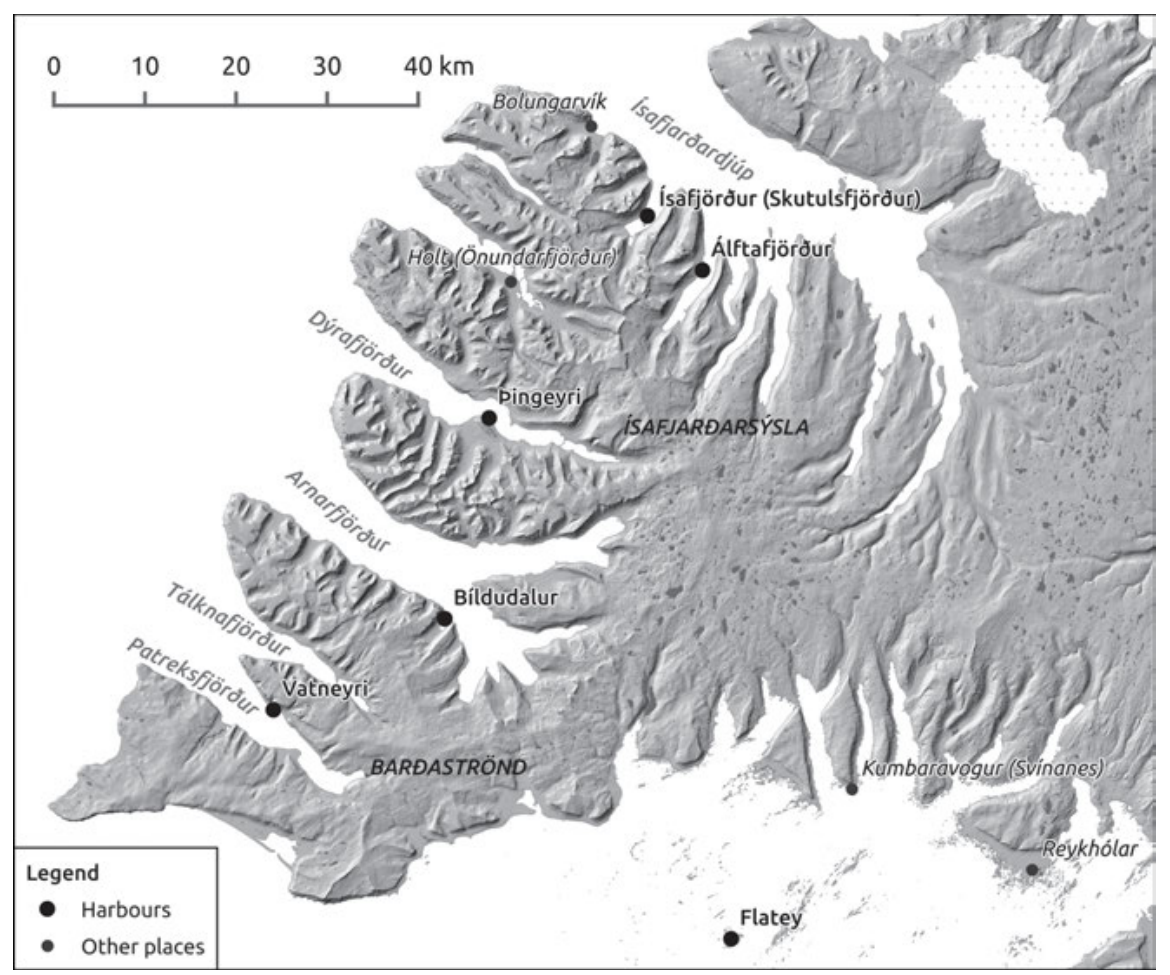

Figure 6.12: Map of trading and other sites in the Westfjords. See Figure 6.1 for location.

\subsubsection{Barðaströnd: Patreksfjörður, Tálknafjörður, and Arnarfjörður}

Names in the sources:

Barðaströnd: Badestrandt (syssel); Bardelsstrandtsissel; Bardenstrand (gebiete); Barnstrandersyssell; Berentstrant

Patreksfjörður: Padersvorde; Patensforde; Patersfiord; Patresfiord; Patrisforde; Patrisvörde; Petersforde; Wathnow.

Bíldudalur: Bildalsforde; Bildal; Bildedal

Tálknafjörður: Tolckesfordt; Tolckevörde; Tolcksforde

The harbours Patreksfjörður and Bíldudalur in Arnarfjörður were characterised as fishing harbours in Danish times and usually used together. This was also the case when the Germans sailed to this area during the sixteenth century, perhaps in tandem with visiting trading sites on the northern coast of Breiðafjörður, especially around Svínanes (Figure 6.12). The Breiðafjörður trading sites being far away from those in Patreksfjörður and Bíldudalur may have been one of the reasons why 
Flatey was first used as a harbour in its own right in the 1580s. ${ }^{194}$ The Danes did not continue the trade in this region. ${ }^{195}$

Before 1565, Patreksfjörður and Bíldudalur were either not used or were considered part of the region around Ísafjörour. The donation register of the confraternity of St Anne mentions ships returning from "Iseforde" or more generally vor westen ('in the west'), but never specifically from these harbours before 1565. The records of Eggert Hannesson also do not list a German ship in Barðaströnd. ${ }^{196}$ It seems reasonable to assume that these harbours were used in earlier times, though, as Patreksfjörður is one of the harbours offered to Hamburg in 1565 as requiring 20 lasts of flour annually, and Tálknafjörður and Bíldudalur together 35 lasts (Table 5.2). ${ }^{197}$ Taken together these fjords approximate therefore the economic value of Hafnarfjörður. Moreover, a complaint from merchants from Stade from 1578 claims that Barðastrandasýsla was visited "traditionally [. . . ] with one ship" every year. ${ }^{198}$ It is therefore quite possible that many of the ships in the donation register that are difficult to link to a specific harbour returned from the Westfjords.

A licence for Patreksfjörður and Bíldudalur was granted in 1565 to Gert Bomhofer, who is referred to in the licence as "wor suouell luterer", i.e. probably the refiner of the recently built royal sulphur refinery in Copenhagen. ${ }^{199}$ Because no sulphur is known to have been mined around the Westfjords, and the licence explicitly forbids trade in it, it is probable that Bomhofer was procuring train oil from the fisheries in the Westfjords, an essential component in the refining of sulphur. ${ }^{200}$ It is not known how long Bomhofer used the harbour. In 1567, Margaretha, the widow of Lübeck burgomaster Bartholomeus

194 See Section 6.3.7 (Flatey).

195 Aðils, Monopolhandel, 303-304.

196 DI 12:323 (Table 5.1).

197 RAK D11, Pakke 26 (Suppl. II. 16) (15650000XXX00). The harbours are called "Patersfiordt", "Tolkefiordt", and "Billingervoge" in this source; the identification of the last as Bíldudalur is uncertain. The German name shares more similarities with the fishing settlement Bolungarvík near Îsafjörður, but this was far from Tálknafjörður, with Dýrafjörður in between, which is also mentioned as a separate harbour in the document ("Direfiordt"). It therefore makes no sense that it was being taken together with Tálknafjörður. The suffix -voge in the name seems to recall Bíldudalsvogur, the bay near Bíldudalur, whereas the Icelandic suffix -vík was usually germanised as -wick (cf. Grindavík, Keflavík, Kumbaravogur, Nesvogur). Both suffixes do indicate a small bay or inlet, however.

198 "die Barnstrandersyssell, in welcher die Padersvorde gelegen von altershero auch nicht hoher und mehr, als mit einem schiffe besiegelt worden”. RAK D11, Pakke 25 (Suppl. II, 15) (15780120STA00).

199 DI 14:240 (15650316BYR00); Mehler, “Sulphur Trade”, 194-195.

200 Mehler, 193-94. See Section 2.2. 
Tinappel who had lost her former husband's licence for Dýrafjörour, applied for a licence for the three harbours in Barðastrandasýsla instead, and was granted a licence for "Alnfiord wdj Issefiordsyssel". It is unclear where this harbour was: one of the options is Arnarfjörður, the northern side of which is located in Ísafjarðarsýsla, but no trading sites are known here (Figure 6.12). ${ }^{201}$

In 1576, Stade merchants (undoubtedly in cooperation with Hamburg merchants) applied for a licence for the harbours Patreksfjörður and Ísafjörður, "and everything in between", i.e. the entire Westfjords. They claimed this area was traditionally visited by two ships annually, one to Barðaströnd and one to Ísafjörður. ${ }^{202}$ Apparently the geography of this region was largely unknown to the Danish authorities, as treasurer Christoffer Valckendorf could not find Patreksfjörður in the register of Icelandic harbours, and therefore assumed that it was Álftafjörður. When the Stade merchants sailed north with two ships the next year, sheriff Eggert Hannesson refused to set the trade in Barðaströnd, as they only had a licence for Ísafjörður and Álftafjörður, both in Ísafjarðarsýsla, and therefore could not sell all their goods. They complained about this situation to the Danish king in $1578,{ }^{203}$ who probably had the error corrected. After their licence expired, Luder Ottersen from Lübeck received one for three years, this time for Vatneyri in Patreksfjörður (Figure 6.12). Vatneyri must have been the main trading place in the region, with the licence probably encompassing the entire region.

In 1586 at the latest, the harbours in Barðastrandasýsla came into the hands of Hamburg merchants. Hans von Kleve acquired a licence that year for "Wathnow in Bardestrandt gebede", i.e. Vatneyri. However, he is attested in the donation register from 1581 onwards, so it is likely that he was sailing under the Stade flag and for Luder Ottersen before. He held his last licence, granted in 1598, together with his son Claus von Kleve. The latter sailed for Danish merchants in the first years of the Danish trade monopoly. In 1604, he claimed that he and his father had traded in Patreksfjörður and Bíldudalur for over 40 years as part of making the complaint that he had been contracted to sail there by merchants from Helsingør, and that the Hamburg merchants formerly trading in Hafnarfjörður were causing him difficulty out of pure jealousy. ${ }^{204}$

201 Aðils, Monopolhandel, 305; Kålund, Beskrivelse af Island, 1877, 1:563-568. See Section 6.4.2 (Îsafjarðarsýsla).

202 RAK D11, Pakke 28 (Suppl. II, 23): request, 23 December (15761223STA00); KB 1576-1579, 151.

203 RAK D11, Pakke 25 (Suppl. II, 15): 20 January 1578 (15780120STA00).

204 SAH 111-1 Islandica, vol. 4: complaint of Claus von Kleve, 17 March 1604 (16040317HAM00). 


\subsection{2 Ísafjarðarsýsla: Dýrafjörður / Ísafjörður / Álftafjörður}

Names in the sources:

Dýrafjörður: Direfiordt; Durefiordt; Dyreforde; Dürförde

Ísafjörður: Isefiordt; Iseforth; Isevorde; Isförde; Issefort; Ißevorde; Ißfiordt; Issfoerde in Schiffelsforth; Schuffelsfiordt; Schoterforde; Skittelsford; Skotzfiordt

Álftafjörður: Altforde; Altenfoerde; Altervorde

Like the fjords in Barðastrandasýsla, the fjords in Ísafjarðarsýsla were usually used together. In Danish times there were two districts: one around Dýrafjörður, covering the western fjords; and one around Ísafjarðardjúp. In good fishing years, there was enough produce to load two ships, but since this was not always the case, the Danes often combined the two districts and sailed there with one ship. In German times, a similar pattern can be discerned. The regions were sometimes licensed separately, sometimes combined, and when combined, the number of ships sailing there varied from one to two per year.

In Dýrafjörður, the trading place was located in Pingeyri at the middle of the fjord from the fourteenth century onwards. ${ }^{205}$ Isafjörður was a small peninsula halfway into Skutulsfjörour (Figure 6.12), on which the modern town of Ísafjörður is located, and was referred to by both the name of the peninsula and of the fjord, of which the latter was the oldest. It was counted among the safest harbours in Iceland. Similar to the situation in Skutulsfjörður, in Álftafjörður a trading site was located on the small headland Langeyri, where in the eighteenth century it is mentioned that there were ruins of a German trading station with ten rectangular and four round buildings with fireplaces where train oil was cooked and a wall protecting the site on the land side. ${ }^{206}$ Aðils considers this place the headquarters of the German traders in the Westfjords, a claim supported by the 1565 list of harbours offered to Hamburg (Table 5.2). Dýrafjörður ("Direfiordt”) and Ísafjörður ("Skotzfiordt”) are mentioned as requiring fifteen lasts of flour each, whereas Âlftafjörður (“Altefiordt”) required double that amount.

English traders were also active here in the fourteenth century, but they probably used the fjords north of Ísafjarðardjúp. ${ }^{207}$ Conflicts with the Germans are not known from this region. Ísafjörour is mentioned for the first time in the donation register of St Anne's confraternity in 1544, but had probably been used for a long time before that by merchants from Hamburg. We

205 Porláksson, "Urbaniseringstendenser”, 170.

206 Aðils, Monopolhandel, 305-306.

207 Aðils, 306. 
hear about the region again in August 1565, when Dýrafjörður in Ísafjarðarsýsla was licensed to Bartholomeus Tinappel, burgomaster of Lübeck and commander of the Danish fleet during the Northern Seven Years' war. In his request for the licence, he stated that Hamburg merchants had sailed to the harbour before with a ship of 70 lasts. ${ }^{208}$ After his death the next year in a battle near Visby, the licence was given to Christof Vogler, the secretary of Segeberg castle. Tinappel's widow Margaretha tried multiple times to continue her former husband's business in the area, ${ }^{209}$ and was eventually granted a licence for "Alnfiord” in September 1567. It is unclear which harbour is meant by this, as she had requested a licence for the fjords in Barðaströnd before, but most likely this was Álftafjörður. ${ }^{210}$ In March of the following year Vogler complained about the interference of Margaretha in his business, to which she replied that her ship had only been there in late 1567 to reclaim outstanding debts. ${ }^{211}$ The complaint made clear that Álftafjörður was considered part of Dýrafjörður, and when Vogler's licence was renewed in 1570, the harbour was specified as covering an area between Geirhólmur and Langanes, which corresponded to the entire Ísafjarðarsýsla. ${ }^{212}$ It is possible that the Lübeck merchants had sailed here up to this point: in 1599 Hamburg merchant Johan Holtgreve claimed that during Christoffer Valckendorf's time as governor of Iceland (1569-1570), Lübeck merchants had traded in Álftafjörður and Christof Vogler in Dýrafjörður. ${ }^{213}$

In 1577, the licence for Îsafjörður and Álftafjörður was given to merchants from Stade for six years, who would sail there with two ships. They likely received permission to sail to Barðaströnd as well the next year, ${ }^{214}$ and evidently left room for one more ship in Ísafjarðarsýsla, as sheriff Eggert Hannesson acquired a licence for Dýrafjörður and Skutulsfjörður in December $1579 .{ }^{215} \mathrm{He}$ partnered with Hamburg merchants, as he is listed in the confraternity's donation register in 1580, together with Hans von Kleve, who would later trade in Patreksfjörður/Bíldudalur. This was nothing new, however: complaints from the Hamburg companions of Christof Vogler in 1567 show that both Vogler and

208 RAK D11, Pakke 26 (Suppl. II, 16): 11 August 1565 (15650811KOB00).

209 RAK D11, Pakke 28 (Suppl. II, 22): requests of April 1567 (15670406LUB00, 15670404LUB00); Pakke 25 (Suppl. II, 15): 4 August (15670804XXX00). See Section 7.4.3.

210 See also Section 6.4.1 (Barðaströnd).

211 RAK D11, Pakke 28 (Suppl. II, 22): 21 February (15680221LUB00); 6 March (15680306LUB00).

212 "aldt forschreffne syssell emellom Gerholm och Langemoesse”. DI 15:266 (15700329ROS00); see Kålund, Beskrivelse af Island, 1877, 1:619.

213 RAK 27 (Suppl. II, 19): request from 1599 (15990000HAM01).

214 See Section 6.4.1 (Barðaströnd).

215 KB 1576-1579, 791 
the heirs of Bartholomeus Tinappel were sailing from Hamburg or cooperating with Hamburg merchants. ${ }^{216}$ The same must have been the case for the Stade merchants. ${ }^{217}$

Although Hamburg ships had therefore probably never been absent in the Westfjords, they were sailing under their own flag again by 1586 at the latest. That year the region was licensed under the name "Ißeforth gebede in Skittelsforde" to Barteld Elers and Cordt Tacke from Hamburg for four years, who received two licences because they wanted to trade there with two ships. When the licences were renewed in January 1593, Roleff Eys replaced Cordt Tacke. Around this time, we hear about an English presence in the region again, as Eys and Elers complained about English attacks in their request for renewal in $1592 .^{218}$

In 1595, Elers and Eys requested a renewal of their licence for Ísafjörður with an extension to Álftafjörour, with the argument that the inhabitants there had complained that they had to travel too far to trade. ${ }^{219}$ This hardly could have been the real reason for the extension, as Álftafjörður was usually considered to be part of the same trading district. It is more likely Roleff Eys was afraid of losing the sole right to trade in the region, as he seems to have had trouble fitting out two ships. Possibly, he lost his trading partner Barteld Elers, who is attested for the last time in the donation register in 1593 (although he is still mentioned in the 1595 request). From 1595 on, only one ship annually from Ísafjörður can be tracked in the register, led by Eys and Conradt Johansen, an Icelander from the region who had settled in Hamburg. ${ }^{220}$ Eys's fears almost came true in 1599, when Johan Holtgreve requested a licence for Álftafjörður with the support of lawman Jón Jónsson, who stated that the region had been traditionally supplied by two ships, but now the merchants were only sailing with one ship, which was not enough for the population. ${ }^{221}$ The licence was not granted, but little did it help Eys and Johansen, as shortly afterwards the Danish monopoly was introduced.

216 DI 15:40 (15670129HAM01); DI 14:416 (15670303LUB00).

217 See Section 3.5.4.

218 RAK D11, Pakke 27 (Suppl. II, 19): requests from 24 and 29 October 1592 (15921024HAM00, 15921029HAM00), repeated on 16 January 1593 (15930116HAM00).

219 RAK D11, Pakke 27 (Suppl. II, 19): request for renewal, 25 November 1595 (15951125HAM01).

220 See Section 4.3.6.

221 RAK D11, Pakke 27 (Suppl. II, 19): requests of August 1599 (15990000HAM00, 15990000HAM01, 15990829THI00). 


\subsection{Northern harbours}

German merchants had litte interest in the fjords in the north. The fish catch was lower than in the west, and in cold years, there was often the difficulty of sea ice in the harbours. ${ }^{222}$ Húsavík and Eyjafjörour were attractive as harbours for the export of sulphur, due to their proximity to the mines around Mývatn. However, King Frederick II in 1561 prohibited non-Danish foreigners from exporting sulphur, and therefore these harbours were not often used by German merchants afterwards. $^{223}$

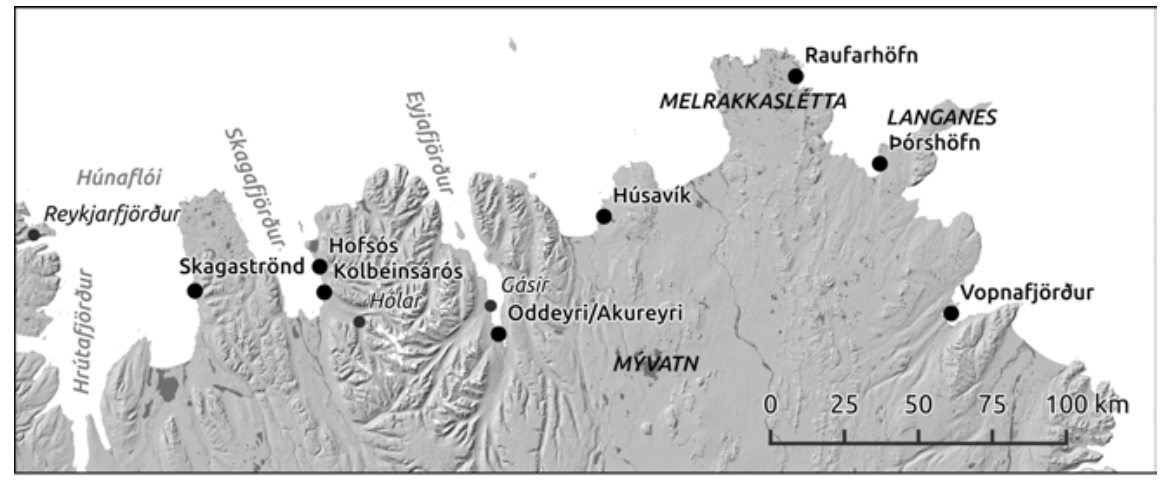

Figure 6.13: Map of harbours and other places in northern Iceland. See Figure 6.1 for location.

\subsubsection{Skagaströnd and Hrútafjörour}

Names in the sources:

Skagaströnd: Schagenstrandt; Schanstrandt; Schavestrantt; Schogesstrand; Spaakonefeldtshoevede; Spakenefiltshovede; Spokonefieldshøffd

Hrútafjörður: Ruterforde; Rutevor; Rutheforde

Skagaströnd was the main harbour in the region of Strandasýsla, encompassing the coast of Húnaflói bay (Figure 6.13). It was located on the eastern side of the bay, on the grounds of the farm Spákonufellshöfði, by which name the harbour was also known to the Danes. ${ }^{224}$ In German sources, we find the name "Spakonefeldtshovede" only in 1602, when a Helsingør ship under

222 See Sections 4.1.2 and 6.2.3.

223 See Section 3.5.3.

224 Aðils, Monopolhandel, 309-310. 
Hamburg merchant Johan Holtgreve set course for the harbour. ${ }^{225}$ On the western side of the bay was the trading site Reykjarfjörour, which was known in Danish times as a train oil harbour, and which was often used together with Skagaströnd. ${ }^{226}$ There is no evidence for German presence here, but it is not impossible that merchants in Skagaströnd visited it now and then.

The first evidence for German presence in Skagaströnd is late; in 1586 a licence was requested by Ratke Timmerman from Hamburg, who stated that the harbour had not been used for several years. ${ }^{227}$ The licence was granted for four years, and renewed every three years afterwards, although it changed hands often. In 1590, the licence was issued to Peter Sivers after he claimed that Timmerman did not want to sail there anymore, ${ }^{228}$ and after Sivers' death Jurgen Vilter was granted the licence in December 1595, who partnered with Sivers' widow until the introduction of the Danish trade monopoly.

The sparse presence of foreign merchants in the region was particularly inconvenient for the inhabitants of the western and southern coasts of Húnaflói, as Skagaströnd was far away and so they had to travel overland to Ísafjörður or Snæfellsnes to trade. With the backing of lawman Jón Jónsson, German merchants therefore tried to acquire licences for Hrútafjörður, southwest of Skagaströnd. In 1592, the fjord was licensed to Peter Sivers' former servant Laurens Schroder and Jochim Holste. However, they promised not to use it after Sivers complained that it was too close to Skagaströnd, and stated that he sometimes went to Hrútafjörður himself to buy train oil and salmon. ${ }^{229}$ In 1594 and 1597, Hans Elers and Jurgen van Winsen made attempts to acquire a licence, ${ }^{230}$ which was granted the second time. The enterprise met with many setbacks, however. A complaint from 1603 mentions that two subsequent ships in 1599 and 1600 had been severely damaged, which had forced the merchants to leave their goods behind, and that they had experienced a great deal of difficulty when they went to retrieve those goods in 1602 , due to an abundance of sea ice. ${ }^{231}$

225 See Section 6.2.3 (Básendar).

226 Aðils, Monopolhandel, 307-309.

227 RAK D11, Pakke 28 (ad Suppl. II, 25): list of harbours licensed to Hamburg (15860213HAM00).

228 RAK D11, Pakke 26 (Suppl. II, 18a): request of 26 August 1589 (15890826HAM00).

229 RAK D11, Pakke 26 (Suppl. II, 18a): request, January 1592 (15920112HAM00, 15920115HAM00); declaration of Joachim Holste, 11 February (15920211KOB00); complaint of Peter Sivers, 7 March (15920307HAM00).

230 RAK D11, Pakke 25 (Suppl. II, 15): 1594 (15940000HAM00); Pakke 27 (Suppl. II, 18a): 15 November 1597 (15971115ITZ00).

231 SAH 111-1 Islandica, vol. 4: 8 April 1603 (16030408HAM00). See Section 4.1.2. 


\subsubsection{Skagafjörður (Hofsós)}

Names in the sources:

Skagafjörður: Schagefordt; Schagenfrende; Schagevor; Schavenforde; Skagefjord; Skaufiord

Hofsós: Hoffaus; Hofsas; Hofsos; Hops Aaess; Koffaus

The bay of Skagafjörour was important as an access point to the bishopric of Hólar. The harbour was initially located at the mouth of the Kolbeinsá river, hence the name Kolbeinsárós. While an overview of German licences compiled around 1600 does mention "Kolbensoß", it is stated that a licence for the place was never issued. ${ }^{232}$ The focus of trading in Skagafjörour shifted north to Hofsós during the sixteenth century, and licences only mention Hofsós or Skagafjörður. As the second name indicates, the trading district encompassed the entire bay, but it is known that inhabitants from Skagafjörður's western coast sometimes traded in Skagaströnd in Danish times, and those from northern Eyjafjörður in Hofsós (Figure 6.13). ${ }^{233}$

There is evidence for an English presence in Skagafjörour in 1431, when the Englishman John Craxton was bishop of Hólar. ${ }^{234}$ In the late fifteenth or early sixteenth century, Hamburg merchants must have taken over, and they are mentioned as having overwintered in Kolbeinsárós in $1524 .{ }^{235}$ Hamburg skipper Henrick Witte is attested in Hofsós in 1552. ${ }^{236}$ However, in December 1564 Danish merchant Hans Nielsen was granted a licence for Hofsós, allegedly because the Hamburg merchants were not bringing commodities of good quality and were deceiving the inhabitants. ${ }^{237}$ The real reason for giving the licence to Nielsen must have been related to the sulphur trading ban, which had been proclaimed in 1561: Nielsen had been tasked with leading the two royal ships going to northern Iceland to fetch sulphur for the next ten years. ${ }^{238}$ These ships were sailing to Eyjafjörður and Húsavík, from where merchants from Hamburg and Lübeck had been exporting sulphur. It is very probable that Hamburg merchants had moved their sulphur trade to Skagafjörour after 1561, and that this was the illicit trade that prompted the king to give Hans Nielsen the sole right to trade in Hofsós. This is also indicated by the combined licence for Skagafjörour,

232 RAK D11, Pakke 24 (Suppl. II, 8): list of licensed harbours, 1601-1603 (16010000XXX00).

233 Aðils, Monopolhandel, 311-312; Porláksson, “Urbaniseringstendenser”, 168.

234 DI 4:516, 518.

235 Baasch, Islandfahrt, 106n11.

236 DI 12:323 (Table 5.1).

237 DI 14:227 (15641204NYB00).

238 Aðils, Monopolhandel, 45; KB 1555-1560, 422. 
Eyjafjörður, and Húsavík granted to Copenhagen burgomaster Marcus Hess for four years in 1572: Hess was allowed to trade in sulphur and train oil and made use of the royal ship. ${ }^{239}$ When Hess wanted to change the terms of the licence after four years, the king decided to take the sulphur trade into his own hands again, and asked Christoffer Valckendorf to fit out two ships to sail to northern Iceland. The merchant leading the enterprise this time was Rasmus Pedersen. ${ }^{240}$ Skagafjörður must not have been part of this trade anymore, as in 1580, bishop Guðbrandur Porláksson of Hólar was granted a licence for Hofsós, which explicitly prohibited him from trading in Eyjafjörður. He bought a share of a ship from Hamburg, which wrecked on the first voyage. ${ }^{241}$

Hamburg merchants must have returned to Skagafjörður not long after this failed enterprise. ${ }^{242}$ In 1586 Matthias Eggers was granted a licence for the harbour with a four-year term, which was renewed every three years after it expired. However, Matthias Eggers is attested in the donation register as having sailed here with Ratke Timmerman (who would receive a licence for Skagaströnd in 1586) in 1580-1585 already. In 1595, Eggers drowned in the Elbe while preparing to sail to Iceland, on which occasion new licences were requested immediately by both Albert Sivers and Matthias' son Hans. ${ }^{243}$ A licence was granted to both of them together, and renewed for the last time in 1598.

\subsubsection{Eyjafjörður (Akureyri)}

Names in the sources: Egefjord; Eyaforde; Eyeforde; Oddenfiordt; Oevarder; Oeverde; Oevorde; Oyefordt; Ødefior havn; Ugforde

239 NRR 2, pp. 4-5 (15720120NYB00); KB 1571-1575, 229-230. Hamburg merchants complained a year later that despite Marcus Hess having the licence, duke Adolf of Holstein-Gottorp was preparing a ship to sail there, under the Hamburg skipper Herman van Horsten. (RAK D11, Pakke 26 (Suppl. II, 16) - 15730419HAM00, 15730420HAM00). It is not known whether van Horsten ever sailed there; the duke was granted permission in 1575 to send a ship to northern Iceland, though it was not allowed to trade in Skagafjörður, Eyjafjörður, or Húsavík (KB 1571-1575, 580).

240 KB 1576-1579, 13; Aðils, Monopolhandel, 46.

241 KB 1580-1583, 44-45; Ketilsson, Kongelige Allernaadigste Forordninger, 98-99; Aðils, Monopolhandel, 59; cf. Gunnarsson, Monopoly Trade, 54.

242 Evidently they had been sailing to Skagafjörður before, because Marcus Hess complained in 1573 that Hamburg and Bremen merchants were active in the three northern harbours where he was trading. KB 1571-1575, 248.

243 RAK D11, Pakke 27 (Suppl. II, 18b): requests, July and August 1595 (15950703HAM00, 15950703HAM01, 15950822HAM00). 
On the western shore of the bay Eyjafjörour is Gásir, the largest known medieval trading site in northern Iceland. The still-extant ruins, the subject of extensive scholarly investigation, consist of many booths along the beach and a church. It was used as a trading site mainly by Norwegian merchants, and lost importance when the area silted up. Ceramic finds of northern German provenance suggest that the site was used into the fifteenth century. ${ }^{244}$ Later the trading site moved to Oddeyri/Akureyri, which was better for larger ships and had a reasonably secure harbour. ${ }^{245}$ Eyjafjörour and Húsavík, and to a lesser extent Hofsós, were the chief harbours for the export of sulphur from the mines around Mývatn. This trade from Eyjafjörður began quite early, as is attested by archaeological finds in Gásir. ${ }^{246}$

The riches of sulphur attracted merchants from various countries in the fifteenth and sixteenth centuries, including Hamburgers. In 1532, Hamburg merchants complained that four years before, the Englishman John Willer had attacked and sunken the ship of Hinrick van Ronne in Eyjafjörður and killed 36 people on board, including Van Ronne. ${ }^{247}$ That same year and again four years later, Hamburg merchants wrote to the bishop of Hólar asking that they be protected from Dutch merchants in Húsavík and Eyjafjörður. ${ }^{248}$ As in southwestern Iceland, the Hamburg merchants came to dominate the trade, and in the donation register of the confraternity there are many years in which sulphur was donated from a pair of ships who sailed north, probably to Eyjafjörour and Húsavík. Ships from Lübeck are mentioned to have picked up sulphur in these harbours as well. ${ }^{249}$ In 1552, we find both the ship of Hans Buneke from Hamburg and the ship of Claus Rode from Lübeck in Eyjafjörður, and the ship of Otto Bade from Hamburg in Húsavík (Table 5.1).

The year 1561 brought an unwelcome change, as King Frederick II closed the sulphur trade to non-Danish foreigners. ${ }^{250}$ Rasmus Pedersen continued the sulphur trade on behalf of the Danish king after Marcus Hess' licence expired in 1577. The royal ships continued to sail to the sulphur harbours until 1598, when a licence for Eyjafjörður was granted to seven merchants from Copenhagen for four years. $^{251}$ Curiously, Andreas Selman from Hamburg was given a licence for

244 Gardiner and Mehler, “Trading and Fishing Sites”, 389-391.

245 Porláksson, “Urbaniseringstendenser”, 167.

246 Aðils, Monopolhandel, 45; Mehler, "Sulphur Trade”, 197-199.

247 DI 16:294 (15320000HAM00). The appearance of Willer in Básendar in 1532 sparked the violent events between the Germans and English that summer. See Section 6.2.3 (Básendar).

248 DI 9:529; 16:341 (15360525HAM00); Thomas, Onze IJslandsvaarders, 11.

249 Mehler, "Sulphur Trade”, 196.

250 See Section 3.5.3.

251 KB 1596-1602, 267-268; Aðils, Monopolhandel, 46. 
Eyjafjörður only two years later. According to an overview of licences from around 1601, the Copenhagen citizens had given up their licence. ${ }^{252}$ This might have to do with overexploitation of the Mývatn mines towards the end of the sixteenth century. ${ }^{253}$ Together with the opening of sulphur mines on the European continent, about which Stefan Loitz had complained back in the 1560 s, $^{254}$ at this point the profit to be made from the Icelandic sulphur trade must have declined steeply. It is significant that in Danish times, Eyjafjörður and Húsavík were known as slaughter harbours and provided reasonable amounts of fish, indicating that their importance as sulphur harbours had diminished. ${ }^{255}$

\subsubsection{Húsavík}

Names in the sources: Husawick; Husevig; Husewick; Huswigk

As sketched above, Húsavík was a leading harbour for the export of Icelandic sulphur. It was a dangerous harbour, ${ }^{256}$ and possibly for that reason it was closely associated with Eyjafjörður, which was more secure, although a bit further removed from the sulphur mines at Mývatn (Figure 6.13). That Húsavík was considered part of Eyjafjörður becomes clear in 1600, when Michael Barchstede from Oldesloe, who had traded in England before, requested a licence for Húsavík and "Schlete" (Melrakkaslétta in the very northeast of Iceland, which had been a harbour in earlier centuries). ${ }^{257}$ Barchstede's request was declined because these places belonged to Eyjafjörður, for which Hamburg merchants already had a licence. ${ }^{258}$

252 "Dieße haffe haben vor dießer zeit ettliche burger von Copenhagen besegelt, aber hernach selbst abgestanden und nicht lenger besegelen wollen”. RAK D11, Pakke 24 (Suppl. II, 8) (16010000XXX00).

253 Mehler, "Sulphur Trade", 197.

254 RAK D11, Pakke 30 (Suppl. II, 35): complaints of Stefan Loitz, 1564 (15640811KOB00, 15641203STE00, 15641204STE00). See also Section 3.5.3.

255 Aðils, Monopolhandel, 314-315.

256 Aðils, 315.

257 Kålund, Beskrivelse af Island, 1882, 2:188-189.

258 RAK D11, Pakke 24 (Suppl. II, 11): request, 2 January 1600, with rejection on the back (16000102OLD00). 


\subsubsection{Pórshöfn}

Names in the sources:

Pórshöfn: Dureshave; Dureßhaffe; Thoreshafen; Thorshøffnn; Thorshöfn; Toureshavenn; Tourishafenn; Tureshave; Turshaf

Raufarhöfn: Rodershave; Rödereshaven

In the very northeast of Iceland, between Melrakkaslétta and the narrrow headland Langanes, lies the fjord Pistilfjörður with the harbour Pórshöfn on its southern coast and the harbour Raufarhöfn on its northwestern coast (Figure 6.13). The area is known from licences to Hamburg merchants as "Dureshave" or "Rödershaven" in/or "Langenes" from 1588 onwards. Located reasonably close to Húsavík and Eyjafjörður, the trade here was probably an attempt to tap into the resources of these northern harbours, which were still off-limits to German merchants in 1588. This strategy undoubtedly had the support of the local population, who had to travel a very long and difficult way to Húsavík or Vopnafjörour. The Danes did not carry on the trade in Pórshöfn. ${ }^{259}$

A licence for Pórshöfn was requested in November 1587 by Hamburg merchant Joachim Warneke, on the grounds that the harbour had become available recently. ${ }^{260}$ It is not known who was trading there before, nor if the licence was granted to Warneke. He is indicated in the donation register of the confraternity of St Anne as having sailed there with a small ship (with seven to eight people), but he is also attested in earlier years as a partner of Joachim Focke, who held a licence for "Ostfriedenes" (Hornafjörður) at the time, so he might also have sailed to another harbour. In any case, the request for a licence for Pórshöfn by Cordt Basse, Hans Hering, and Hans Schomaker in 1589 does not mention Warneke. ${ }^{261}$ The licence was granted for three years; since the three licence holders cannot be identified in the donation register in those years, they probably contracted someone else to sail on their account. ${ }^{262}$

In 1592, Cilie, the wife of Paul Lindeman, who had had a licence for Vopnafjörður, asked that the licence be renewed and combined with the licence for Pórshöfn, which her son Hans Lindeman would share with Basse, Hering, and Schomaker. The reason was that Paul Lindeman had had trouble in two consecutive years with Scottish pirates, and moreover had not been able to sell all his goods because of the small size of the trading district. Cilie claimed that instead of sailing to each harbour with a small ship, they would combine forces and sail

259 Aðils, Monopolhandel, 316.

260 RAK D11, Pakke 26 (Suppl. II, 16): 9 November 1587 (15871109HAM00).

261 RAK D11, Pakke 26 (Suppl. II, 18a): 12 May 1589 (15890512HAM01, 15890512HAM02).

262 See Section 7.2.4. 
with a bigger ship, so that they could better defend themselves against pirates and the trade would be more viable. ${ }^{263}$ Instead of being granted a combined licence, as they had asked, however, they received separate licences for Pórshöfn and Vopnafjörour, which continued to be the case from this point onwards.

The result of this was that ships sailed to Vopnafjörður while Pórshöfn was largely ignored. In the winter of 1594/5, Hinrich Moller therefore tried to acquire a licence for Pórshöfn with the help of four Icelandic priests from the region, who claimed that merchant Jacob Winock had promised to come to trade but had never showed up. ${ }^{264}$ Hinrich Moller is attested on the same ship as Winock in 1594, which suggests that the latter was the merchant trading in Vopnafjörður. He is also recorded as holding the licence for Vopnafjörour together with Cordt Basse and Hans Hering in November 1594. The next year, Joachim Focke tried to acquire a licence for Pórshöfn, with the help of sheriff Vigfús Porsteinnsson, who claimed that the inhabitants of Pingeyrarping had to travel too far to the Danes in Eyjafjörður. ${ }^{265}$ This time a licence for Langanes was granted to Focke for three years, who held a licence for "Ostfriedenes" at the same time. Curiously, though, the licence for Basse and Hering was extended for three years as well in 1598, and the last time in 1600.

\subsection{Eastfjords}

South of Langanes begins the region Austfirðir (Eastfjords), where trading seems to have been least attractive for German merchants, and very little mention is made of it in the donation register of St Anne's confraternity. Paradoxically, there are a great many sources pertaining to the region, as disputes between merchants about the right to use certain harbours in the late sixteenth century were frequent. This stemmed in large part from vagueness about the names of licensed harbours, which also makes it difficult to reconstruct the trading history of this area. Based on the information from the donation register of the Hamburg confraternity, the region was visited by a few small ships from Hamburg, who sometimes worked together and sometimes not. However, Bremen merchants had been in the region the longest.

263 RAK D11, Pakke 26 (Suppl. II, 18a): requests of 18 and 26 February and 10 March 1592 (15920218HAM00, 15920226HAM00, 15920310HAM00).

264 RAK D11, Pakke 24 (Suppl. II, 9): testimonies from Icelanders, 1594 (15940800VOP00, 15940826VOP00, 15940901HOF00); Pakke 27 (Suppl. II, 18b): request, February 1595 (15950219HAM00, 15950215HAM00).

265 RAK D11, Pakke 24 (Suppl. II, 9): complaint of Vigfús Porsteinsson, 1595 (15950730HAG00). 
The eastern district of Múlasýsla was divided into three parts, each with its own harbour and trading district in Danish times: Vopnafjörður, Reyðarfjörður, and Berufjörður. ${ }^{266}$ However, when the region was visited from c. 1500 by Bremen merchants, it was only referred to broadly as "Ostforde"; this name did not denote a specific harbour. ${ }^{267}$ The division of harbours that is known from Danish times seems to have crystallised during the struggles in this region between German merchants from different cities during the second half of the sixteenth century.

\subsubsection{Vopnafjörður}

Name in the sources: Wapenforde; Wapenfoirt; Wapenfoyrtt; Wapenfurdt; Wapenfürth; Wapenvohrde; Wapfenfiortt; Wepenforde; Wognneffiord; Wopnefiorde

Vopnafjörður, the northernmost of the eastern harbours (Figure 6.1), was the first to become more specifically defined when Herman Oldenseel from Lübeck received a licence for it in February 1566. The text of the licence clearly distinguishes this harbour from "Ostforde", which was in use by Bremen merchants. This did not stop Bremen merchants from coming to Vopnafjörour: Oldenseel complained that Bernd Losekanne, Christoffer Meyer, and Dirick Vasmer visited the harbour in $1567 .^{268}$

Herman Oldenseel was not the first to sail here, however. During the dispute between Hamburg and Bremen merchants in Berufjörður in 1580, Matthias Eggers stated that Hamburg merchants had traded in "Ostforde" for over 40 years, and listed them in chronological order: Hans Hartich, Hans Tinsdal, Roleff Hummelsen, Bernd Salefeld, and himself. ${ }^{269}$ The Bremen merchants replied that the Hamburg merchants had actually been trading in Vopnafjörður. ${ }^{270}$ Before 1566 and after 1568, these Hamburg merchants can indeed be traced in the donation register. In February 1576, Copenhagen burgomaster Marcus Hess was granted a licence for Vopnafjörður together with Hafnarfjörður for three years, ${ }^{271}$ but afterwards Hamburg merchants were active there again.

In 1586, Cordt Botker and Paul Lindeman acquired a licence for Vopnafjörour, though both had been active there since approximately 1580, after Matthias Eggers moved his business to Hofsós. Apparently they had held a licence for

266 Aðils, Monopolhandel, 316-317.

267 See Section 6.6.3 (Berufjörður).

268 DI 14:419 (15670310KОВ00).

269 SAB 2-R.11.ff.: defence of Matthias Eggers, 25 January 1580 (15800125HAM00).

270 SAB 2-R.11.ff.: response of Bremen merchants, 15 February 1580 (15800215BRE00).

271 KB 1576-1579, 15-16. 
Vopnafjörður before 1586 as well, because in 1583 Paul Lindeman's ship was confiscated when he traded in a harbour for which he was not licensed. ${ }^{272}$ The fact that Botker and Lindeman asked for two separate licences in 1586 indicates that both were often sailing around the region with their own ships. ${ }^{273}$ This is reflected in the donation register of St Anne: they are sometimes on the same ship, and other times on different ships, not infrequently in cooperation with Joachim Warneke or Joachim Focke, who are also mentioned in the 1580s as interfering with the trade of Bremen merchants in Berufjörður. ${ }^{274}$

Paul Lindeman's activity in Vopnafjörður can be tracked until 1589, when he is last mentioned in the donation register. Due to pirate attacks and a storm, he was unable to visit Vopnafjörour for two years, during which time Hinrich Moller went there instead, eventually requesting a licence in his own name in $1592 .{ }^{275}$ At the request of Lindeman's wife Cilie, the new licence that was issued included Pórshöfn, as has been sketched above. The licence was initially held jointly with Paul Lindeman's son Hans, and from 1594 onwards with Jacob Winock. The latter, however, was not active for a long time as well, and in 1595 and 1598-1601, ships to Vopnafjörður are mentioned in the donation register, usually with skipper Johan Tinsdal and merchants Joachim Focke, Marten Horneman, or Herman Gansberch. Winock was made sheriff in eastern Iceland ${ }^{276}$ and Cordt Basse died, so that Herman Gansberch, Hans Hering, and Claus Olde applied for the last licence in $1600 .^{277}$ An overview of licences compiled one year later, however, mentions that a prolongation was given to Lübeck merchant Luder Ottersen in December 1600, which hints at the possibility that the Hamburg merchants were acting on his behalf in Vopnafjörður, from as well as before that year. ${ }^{278}$

272 SAH 111-1 Islandica, vol. 3: letter of Frederick II, 11 January 1584 (15840111HAV00). The harbour is not mentioned, but was probably Berufjörður.

273 Aðils, Monopolhandel, 318, mentions that Hamburg merchants used to visit Borgarfjörður, south of Vopnafjörður, with a small ship once or twice a year. Travelling around the Eastfjords is also attested for Bremen merchants in Berufjörður (see Section 6.6.3), so that this must have been the common way of conducting trade in the region. This would also explain why most of the ships in the confraternity of St Anne's donation register that can be traced to the Eastfjords list only seven to twelve men on board.

274 See Section 6.6.3 (Berufjörður).

275 RAK D11, Pakke 26 (Suppl. II, 18a): February 1592 (15920223HAM00, 15920226HAM01).

276 See Section 4.4.1.1.

277 RAK D11, Pakke 27 (Suppl, II, 19): 24 October 1600 (16001024HAM00).

278 RAK D11, Pakke 24 (Suppl. II, 8) (16010000XXX00). 


\subsubsection{Reyðarfjörður}

Name in the sources: Roderforde; Rodevorde

Reyðarfjörður is the largest fjord in eastern Iceland and was used as the harbour of the central district of Múlasýsla in Danish times. It was also visited irregularly by German merchants in the Eastfjords. Bremen skipper Bernd Losekanne, who fell out with his companions in Berufjörður in 1576, mentioned that he had been to Reyðarfjörður the year before, and if his fellow traders did not allow him to do business in Berufjörður, they would themselves not be welcome in Reyðarfjörður. ${ }^{279}$ The Hamburg donation register mentions Reyðarfjörður now and then after 1610, which indicates that merchants from that city sailed there for Danish merchants. Finally, Reyðarfjörður might be the place referred to as "Ostfriedenes sonst Hoddenforde", for which Joachim Focke from Hamburg was licensed between 1586 and 1596. In 1599, in a request for prolongation of the licence, the harbour was called "Oestfriedeneß sonst Rodeforde". ${ }^{280}$ As Joachim Focke often worked in concert with the Hamburg merchants in nearby Vopnafjörour and Pórshöfn, this is not impossible. However, the names Ostfriedenes and Hoddenforde have no Icelandic analogy in the region around Reyðarfjörður, and a localisation of this harbour in Hornafjörður is more likely (see Section 6.6.4).

\subsubsection{Berufjörður}

Names in the sources: Berenfordt; Bernfoyrt; Bredeforde; Ostforde; Oestfiordtt; Oßfortt; Ostenforth; Papie; Pappø; Østfiord

Berufjörður was the most important harbour in eastern Iceland, and among the most heavily contested harbours of the entire island. It is the only harbour not in western Iceland in the list of harbours offered to Hamburg in 1565 that requires at least 20 twenty lasts of flour annually (Table 5.2). It was also one of the oldest harbours; on the fjord's northern coast, a trading site known as Gautavík is mentioned many times in the annals from c. 1250 onwards. The ruins of the site have been thoroughly researched. An excavation led by German archaeologist Torsten Capelle in 1979 revealed four complexes of buildings, which largely consisted of small booths. In the western complex, a round

279 SAB 2-R.11.ff.: final plea of Bernd Losekanne, 1576 (15760200BRE00).

280 RAK D11, Pakke 27 (Suppl. II, 18b): 3 February 1599 (15990203HAM00). The name "Rodeforde" could very well be a mistake by the scribe of the city of Hamburg; it does not occur anywhere else in relation to "Ostfriedenes". 
brick structure was found, which has been interpreted as a drying kiln or a storage facility for sulphur or train oil. Many ceramic fragments, mostly from the sixteenth century, are evidence of import from northern Germany. ${ }^{281}$ Recent analysis of 13 redware fragments showed that 12 were produced near Bremen and the remaining one was produced in the Netherlands, which accords with documentary evidence about the dominance of Bremen merchants in the area in the sixteenth century. ${ }^{282}$ Gautavik was abandoned in the later sixteenth century due to silting of the harbour, and a new trading site was established at Djúpivogur at the southern entrance of the fjord (Figure 6.14). ${ }^{283}$

Shortly before 1500 Bremen merchants must have started trading in this region under the name of "Ostforde", ${ }^{284}$ which broadly referred to the entire eastern quarter of the island, although they probably concentrated their trading in Gautavík. In 1582, Bremen merchants made the claim that they had been and still were active across the entire region together with Hornafjörður, first with one ship and eventually with two ships annually, ${ }^{285}$ and in 1567 the region was defined as stretching from Hornafjörður to Vopnafjörður. ${ }^{286}$ The vast extent of the trading area and its unclear definition provided the ground for the many conflicts after the introduction of licences, when harbours became more clearly delineated. Later, by way of referring specifically to the harbour, it was also called "Papie", after the island Papey before the coast of Berufjörður, which one had to pass to enter the fjord, as a document from 1591 indicates. $^{287}$

281 Mehler et al., "Gautavík”, 227-231; Gardiner and Mehler, "Trading and Fishing Sites”, 391-392; Porláksson, “Urbaniseringstendenser”, 170.

282 Mehler et al., 236.

283 Aðils, Monopolhandel, 318; Gardiner and Mehler, “Trading and Fishing Sites”, 392.

284 Documents from the late sixteenth century mention Bremen merchants having been active there for a long time, which all point back to shortly before 1500. On 28 February 1567, they claimed to having traded there for over 70 years (15670228BRE00); on 13 February 1576 for 80 years (15760213BRE00); and on 15 February 1580 for 80 years (15800215BRE00). RAK D11, Pakke 25 (Suppl. II, 15).

285 "wir die have Oistfortt sambt dessenn sussell, unnd dabey gelegene Hornefortt, eine vast geraume unnd lange zeitt von jharenn hero, anfenglich mit einem, hernacher aber alle wege mit zweyen unsern schiffenn [. . .] besiegeldt”. RAK D11, Pakke 25 (Suppl. II, 15): complaint against Hamburg merchants, 18 January 1580 (15820118BRE00).

286 SAB 2-R.11.ff.: instruction for Tyleman Zerneman, 26 September 1567 (15670926BRE00).

287 "diese havinge Oistfiortt auch Papie genandt wirde nun sey aber Papie einn eilandt so bey der Oistfiortt so nahentt liege, das mann dabey hinein ann die have siegelenn muß, unnd dahero umb mehrer gewißheitt willen dieser havinge dieselbige von solchem eilande auch Papie genantt wordenn”. SAB 2-R.11.ff.: instruction for Daniel Bisterfeld, 14 November 1591 (15911114BRE00). 


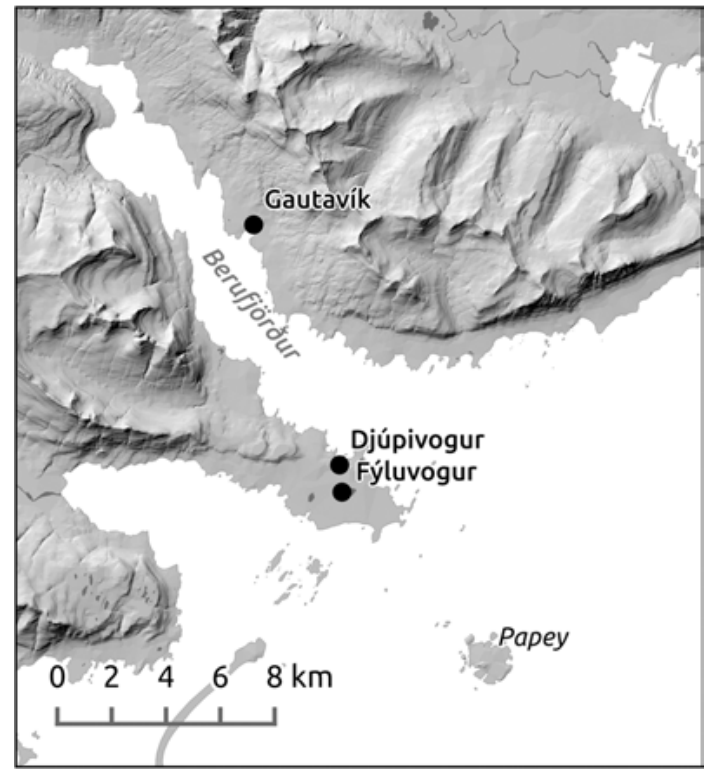

Figure 6.14: Map of locations in and around Berufjörður in eastern Iceland. See Figure 6.1 for location.

At the same time as Herman Oldenseel received his licence for Vopnafjörður in 1566, "Ostforde" was given to Copenhagen merchant Heinrich Mumme. Bremen merchants, however, did not accept this situation and continued to trade in the region, as complaints from Mumme and Oldenseel indicate. ${ }^{288}$ Bremen merchants seem to have had the support of sheriff Eiríkur Árnason, who set the trade with them as per usual in 1567, but complained about the behaviour of the new merchants in Vopnafjörður. ${ }^{289}$ Diplomatic efforts by the Bremen authorities bore fruit in 1569, when Bernd Losekanne received a licence for "Ostforde", although it was decided that Mumme would be allowed to sail there as well until $1570 .{ }^{290}$

In 1572, Losekanne formed a maschup with fourteen others, eight of whom stayed at home. As skipper, Losekanne had the sole right of expelling others from the maschup if they misbehaved on board. ${ }^{291}$ The company was a

288 RAK D11, Pakke 25 (Suppl. II, 15): complaint from Mumme, 1567 (15670201FRE00); SAB 2R.11.ff.: complaint from Oldenseel, 1567 (15670310KOB00); complaint from Mumme, 1568 (15680304KOB00, 15680304KOB01).

289 RAK D11, Pakke 25 (Suppl. II, 15): testimony of Eiríkur, 21 August 1567 (15670821SKR00). 290 DI 15:170 (15690402КОВ00).

291 SAB 2-R.11.ff.: Maschup contract, 16 April 1572 (15720416BRE00). 
continuation of the maschup formed in 1549 that had sailed in the period before 1566. The contract lists Losekanne among ten merchants sailing from Bremen to Iceland, this time under the command of skipper Herman Wedeman. ${ }^{292}$ Many of the other names appear in both contracts as well. ${ }^{293}$

We would not have known about the exact composition of these trading companies, had not a dispute broken out between Losekanne and the others in 1574 . Bernd Losekanne stated that three merchants had mutinied against him in Iceland, whom he decided to expel from the maschup. Back in Bremen, however, the other merchants in the maschup, led by Christoffer Meyer, turned against him and tried to keep the company together. Losekanne thereupon decided to leave the maschup himself and start a new one, equip a ship, hire a crew, and trade on his own account the next year. ${ }^{294}$ This presented the others with a problem, as the licence for the harbour had been issued in Losekanne's name. Moreover, Losekanne had torn the licence to pieces and removed the seal, claiming that the Danish king had given up the licence trade and it was therefore of no use anymore. ${ }^{295}$ Suspecting difficulties in Iceland without a valid licence, Meyer claimed that the licence was valid for the entire company due to their long history of trading together. Bremen's city council decided in favour of Meyer and declared that Losekanne was free to take part in the former maschup, but if he decided not to, he should not interfere with the others' business. ${ }^{296}$

However, Losekanne did not accept the verdict and sailed north anyway. In the spring of 1576, Meyer complained that when they had gone to Berufjörður the previous year, a boat with Losekanne's men was there, whereas Losekanne himself had gone to Reyðarfjörður. Losekanne claimed that his men were subsequently attacked by Meyer's men “with guns, daggers, and fire, like raging wolves", although Meyer claimed that his men had only gotten a little impatient. $^{297}$ Apparently Meyer won the case, as the licence was re-issued in his name in May 1577. Losekanne seems to have continued sailing to the same harbour as well, maybe with his own ship (which could have been when two ships

292 SAB 2-R.11.ff.: Maschup contract, 8 April 1549 (15490408BRE00).

293 See Section 7.2.1.

294 SAB 2-R.11.ff.: final plea of Bernd Losekanne, 1576 (15760200BRE00). See Section 7.2.3.

295 SAB 2-R.11.ff.: declaration of Bremen's secretary, 7 April 1575 (15750407BRE00).

296 SAB 2-R.11.ff.: verdict of the city council, March 1575 (15750325BRE00, 15750328BRE00).

297 "mit buchsen, spießen, brennenden lunten, gleich wie rasende wolffe". SAB 2-R.11.ff.: defense of Losekanne, 6 February 1576 (15760206BRE00); reply of Meyer, 13 February (15760213BRE00). 
began to sail there), or possibly he reconciled with his former maschup. In January 1580, Losekanne and Meyer jointly complained about the interference from Matthias Eggers and Simon Schmidt from Hamburg in "Ostforde” over the previous three years. ${ }^{298}$

This complaint marked the beginning of two decades of struggle between Hamburg and Bremen merchants over the right to trade in Berufjörður. The men from Hamburg claimed to have traded in the region for 40 years, but Losekanne and Meyer replied that they had done so in Vopnafjörður, and had been in Berufjörður only a few times. Once, Hans Hartich even stationed a merchant in nearby “Torniß” (possibly Torfnes in Reyðarfjörður), but when he did not return, Losekanne and Meyer had to take the merchant back to Bremen. ${ }^{299}$ Shortly afterwards, Matthias Eggers seems to have begun to trade in Skagafjörour, but this was not the end of Hamburg presence in the area. Losekanne and Meyer complained again in 1582 and 1583, this time about Joachim Focke and Joachim Warneke, after which governor Johan Bockholt proposed that the matter be discussed at the next Althing. ${ }^{300}$

The support of sheriff Eirikur Árnason for the presence of Hamburg merchants in Berufjörður was crucial. Eggers and his companions defended their trading in the harbour by arguing that they had a general licence from the Danish king for Iceland. Losekanne and Meyer responded that Eirikur Árnason had sold them this licence, in return for money and a share of the ship, and that it had been issued in Eiríkur's name, and not in that of the Hamburg merchants. ${ }^{301}$ Eiríkur had traded with Hamburg merchants before, as he claimed to have stored wadmal in the booth in the harbour in 1575 that was destined for a man from Hamburg named Matthies (i.e. Eggers). ${ }^{302}$ Eiríkur moved to Hamburg later, and appears in the donation register of the confraternity in 1583 and $1584 .^{303}$

A few relatively peaceful years followed the renewal of the licence in 1586 for a Bremen merchant, this time Marten Losekanne (probably Bernd's son) for four years. In 1589, however, the conflict flared up again. Hamburg merchant Daniel Elers had been granted a licence for the harbour "Bereforde", which was the name that the Icelanders used for the fjord (Berufjörður). The situation was

298 SAB 2-R.11.ff.: 23 January 1580 (15800123BRE00).

299 SAB 2-R.11.ff.: defense of Eggers, 25 January 1580 (15800125HAM00); reply of Losekanne and Meyer, 15 February (15800215BRE00).

300 SAB 2-R.11.ff.; RAK D11, Pakke 25 (Suppl. II, 15): correspondence 1582-1583.

301 SAB 2-R.11.ff.: letter from Eggers, 27 February 1580 (15800227HAM00); answer from Bremen, 8 March (15800308BRE00).

302 SAB 2-R.11.ff.: statement of Eiríkur Árnason, 6 August 1575 (15750806SKR00).

303 Koch, Isländer in Hamburg, 150-151. See also Section 4.3.6. 
further complicated when the German Chancery in Copenhagen apparently made an error in the renewal of Losekanne's licence for "Ostforde", issuing him one for Vopnafjörour instead; Elers later used this to underscore that his was the legitimate licence, claiming that Losekanne had changed the harbour on his from Vopnafjörður to "Ostforde" on purpose. ${ }^{304}$ The next summer, Bremen merchants collected testimonies of the inhabitants of Berufjörour and surroundings, in which they stated that Bremen merchants had always served them well for over 80 years. ${ }^{305}$ Bremen secretary Daniel Bisterfeld was sent to the king in autumn of 1590 to present these testimonies and discuss the case, which is the first time that we hear that the Bremen merchants had trading booths in "Fuluwick", probably the bay Fýluvogur, which was not more than a kilometre south of Djúpivogur, the trading site that Hamburg merchants used (Figure 6.14). ${ }^{306}$ Thereupon Marten Losekanne's licence was renewed, but a few months later the king rescinded Losekanne's right to trade in Berufjörður after a visit from Daniel Elers. ${ }^{307}$ In the summer of 1591, both Hamburg and Bremen merchants collected testimonies from Icelanders, which either confirmed or denied the existence of a harbour called "Ostforde" and a trading site called "Fuluwick". ${ }^{08}$ Once again, Daniel Bisterfeld was sent to the Danish court, but nothing changed. ${ }^{309}$ The Danish administration decided that it was impossible to decide which party was right, and confirmed the status quo. ${ }^{310}$

From now on, licences for Hamburg merchants were issued as "Bereforde" with the main trading site "Dupwage" (Djúpivogur), and those for Bremen merchants as "Ostforde in Ostfortsussel" with the main trading site "Fuluwick". Of the Bremen merchants, Marten Losekanne remained active, from 1595 onwards jointly with Johan Oldenbuttel and Johan Reineke's widow, and from 1598 with

304 RAK D11, Pakke 26 (Suppl. II, 18a): letter of Daniel Elers, 1591 (15910000HAM00).

305 RAK D11, Pakke 26 (Suppl. II, 16, 18a) (15900526FUL00, 159000000ST00, 15900812FUL00, 15900813FUL00, 15900820FUL00, 15900827FUL00, 15900829FUL00).

306 SAB 2-R.11.ff.: instruction for Bisterfeld, 14 October 1590 (15901014BRE01). Bisterfeld also requested a licence for "Klevesohe in Lon" on behalf of Friedrich Tilebare. This was probably the lagoon Lón south of Berufjörður (Figure 6.1), where the River Jökulsá came down from the gletsjer Vatnajökull, which was also known as Klofajökull, hence the name "Klevesohe". Kålund, Beskrivelse af Island, 1882, 2:268. There are no other references to trade in Lón, so the licence was probably never used, if it was ever granted in the first place.

307 RAK D11, Pakke 26 (Suppl. II, 16): letter of Christian IV, 7 May 1591 (15910507KOB00).

308 RAK D11, Pakke 26 (Suppl. II, 16) (15910700BER00, 15910000ISL00, 15910825GET00, 15910821EYO00, 15910824FUL00, 15910819SLE00, 15910826FUL00, 15910821VIK00, 15910811BER00).

309 SAB 2-R.11.ff.; RAK D11, Pakke 26 (Suppl. II, 18a): instruction, 14 November (15911114BRE00). 310 KB 1588-1592, 739; Aðils, Monopolhandel, 56-57. 
Friederich Tilebare as well. As for the Hamburg merchants, Daniel Elers remained the licence holder, but he is never attested in the donation register of the confraternity. Instead, Joachim Focke or Joachim Warneke must have traded in Berufjörður for him. After his death, the licence was granted in 1598 to Jacob Fincke from Flensburg for three years.

\subsubsection{Hornafjörður}

Names in the sources: Ostfriedenes sonst Hoddenforde; Ostfriederneshaffe; Harneforth; Hornefiordt

One of the most puzzling place names in Iceland is "Ostfriedenes sonst Hoddenforde”, which was licensed to Joachim Focke from Hamburg from 1586 onwards. This might be a corruption of "Oddenforde", which was sometimes used for Eyjafjörour, although this is unlikely, due to the Danish presence in Eyjafjörður; a more likely option is Hornafjörður (Figure 6.1). ${ }^{311}$ Due to the Icelandic pronunciation of the letter combination $m$ sounding more like $d n$, a corruption from Hornafjörður to "Hoddenforde" is not unlikely. Moreover, Hornafjörður is often mentioned in combination with "Ostforde", and the site is known to have been used by German merchants, with the ruins of booths still being somewhat visible in the nineteenth century. ${ }^{312}$ Joachim Focke is known to have been active in eastern Iceland, due to the frequent alliances with merchants in Vopnafjörður or Pórshöfn mentioned in the donation register of the Hamburg confraternity. More difficult to interpret, however, is the addition "Ostfriedenes", which might refer to Austurfjörutangi, the strip of land that closed off the lagoon Hornafjörour to the east, and which had to be passed to enter the harbour, which is located in a bay accessible from the eastern side of the headland (nes) in the middle of the lagoon. ${ }^{313}$

Hornafjörour is mentioned in annals as a landing place for English merchants on their way to western Iceland in $1413,{ }^{314}$ and also seems to have been frequented by Bremen merchants from early on. During the dispute with his companions in 1576, Bernd Losekanne stated that his brother Johan had first sailed to "Ostforde", whereas he himself had first traded in "Horneforde" with Herman Wedeman, before they had moved on to "Ostforde" and founded the maschup in $1549 .{ }^{315}$ In subsequent years the place continued to be used by

311 A third unlikely candidate is Reyðarfjörður; see Section 6.6.2.

312 Kålund, Beskrivelse af Island, 1882, 2:271.

313 Kålund, 2:271.

314 Skúlason, “Hafnarfjörður”, 184-185.

315 SAB 2-R.11.ff.: final plea of Losekanne, 1576 (15760200BRE00). 
Bremen merchants from Berufjörður, and in 1582 and 1583 the region was still being referred to as "Ost- und Horneforde". 316 The acquisition of the licence for this fjord under the alternative name "Ostfriedenes sonst Hoddenforde" in 1586 might therefore be considered a trick to gain access to this fjord by deceiving the German Chancery. It might also be the reason why there is little evidence for Hamburg-Bremen conflict in the region between 1586 and 1589. Curiously, however, there is no evidence for Bremen attempts to prevent Focke from using his licence. The licence was renewed every two to three years until 1596, when Focke also received a licence for Langanes. When he tried to return to Hornafjörður, Jacob Winock, who had become sheriff of Múlasýsla in the meantime, noticed that this was the "Ost- und Horneforde" for which Friedrich Tilebare from Bremen already had a licence, and enquired for details at the German Chancery. ${ }^{317}$ It is unlikely that a new licence was ever granted.

316 SAB 2-R.11.ff.: letter from Bremen, 24 March 1582 (15820324BRE00); letter from governor Johan Bockholt, February 1583 (15830200KLIO0).

317 RAK D11, Pakke 27 (Suppl. II, 19): 24 August 1599 (15990824SKR00). See Section 4.4.1.1. 
